Ankara Üniversitesi Türk Inkllâp Tarihi Ensitüsü Atatürk Yolu Dergisi S 24, Kasim 1999-2003 s. 417-467

\title{
11 Nisan 1920 (1336) Tarihli Takvim-i Vekâyi’de Kuva-yı Milliye Aleyhinde Yayınlanan Kararlar
}

\author{
Yrd. Doç. Dr. Osman AKANDERE* \\ ÖZET
}

5 Nisan 1920 tarihinde dördüncü defa hükûmeti kurmakla görevlendirilen Damad Ferid Paşa, daha önceki hükûmet dönemlerinde olduğu gibi, bu defa da Mustafa Kemal Paşa önderliğinde Anadolu'da her geçen gün biraz daha gelişen Millî Mücadele Harekâtı'nı yok etmek amacıyla harekete geçmişti.

Millî Mücadele aleyhinde yapacağı faaliyetler ve alacă̆ı kararlar konusunda Ingilizlerle tam bir işbirliği içerisinde olan Damad Ferid Paşa ve Hükûmeti, onların desteğini de sağlamıştı.

Padişah'ın ve İstanbul Hükûmeti'nin Anadolu'da yeniden otorite tesis etmesi için, Kuva-yı Milliye'nin ve bu hareketin Mustafa Kemal Paşa önderliğindeki lider kadrosunun suçlanması ve küçük düşürülmesi gerekiyordu. Bunun için iktidarının daha ilk günlerinde bu amaca yönelik olarak bazı kararlar alınmıs ve bunlar dönemin resmi gazetesi olan Takvim-i Vekâyi'de yayınlanmıstı.

11 Nisan 1920 tarihli Takvim-i Vekâyi'de yayınlanan "Padişah'ın Hatt-l Hümayunu, Damad Ferid Paşa Hükûmeti'nin Beyannamesi ve Şeyhülislam Dürrîzâde Abdullah Efendi'nin Fetva-yı Şerife'si" ile Kuva-yı Milliye Harekâtı ve bu hareketin lider kadrosu ; anayasa ve kanunlara karşı gelen, Padişah ve Halife'ye isyan eden, ülkenin iç huzurunu bozan, ülkeyi parçalamak isteyen kişiler olarak suçlanmişlardı.

Türk kamuoyunu etkilemek amactyla yayınlanan bu kararlar gerçektende Millî Mücadele'ye büyük zararlar vermişti. Anadolu'nun her tarafinda Millî Mücadele'ye karşı isyanların çıkmasına, millî kuvvetlerden firarlara ve her türlü ihanetlere neden olmuştu.

Anahtar Kelimeler: Takvim-i Vekâyi, Damad Ferid Paşa, Hatt-ı Hümayun, Hükûmet Beyannamesi, Fetva-yı Şerife.

• Selçuk Üniversitesi Teknik Bilimler Meslek Yüksekokulu Türkiye Cumhuriyeti Tarihi ve Atatürk İlke ve İnkılâpları Dersi Öğretim Üyesi. 


\title{
The Decisions Against National Forces Published In Takvim-I Vekayi On 11 April, 1920 (1336)
}

\begin{abstract}
Damad Ferid Pasha, appointed to set up the government for the third time 5 April 1920, set out to demolish the National Struggle Action, under the leadership of Mustafa Kemal Pasha, which had been developing day by day.

Damad Ferid Pasha and his government, who were cooperating fully with the English on the task and decisions against the National Struggle Action, had also obtained the support of them.
\end{abstract}

Then, it was necessary that the Sultan reestablished his authority and the Act of National Force and leaders under the command of Mustafa Kemal Pasha had to be blamed and scorned. For this reason, even on the first days of the Government, some decisions leading to this aim were taken and published in Takvim-i Vekayi, the official newspaper of the age.

The Act of National Force and leaders were blamed for Hatt-i Humayoun published on 11 April 1920, The Declaration of Damad Ferid Pasha Government Sheikhulislam Dürrizade Abdullah Efendi's Fetva Sherif were blamed for acting as the rebels who violated the law an constitution, rebelled against the Sultan and the Haliphate and broke the peace in the country.

These decisions published in order to affect the Turkish public relay destroyed our National Struggle Act. They caused the great rebellions against The National Struggle Act and escapes and betrayals in the National Forces.

Key Words: Takvim-i Vekayi, Damad Ferid Pasha, Hatt-i Humayoun, The declaration of the Government, The decision of Sheikhulislam

\section{Giriş}

İlk sayısı 11 Nisan 1831 tarihinde yayınlanan Takvim-i Vekâyi ${ }^{1}$, çıkarıldığı ilk günden itibaren Osmanlı Devleti'nin resmi gazetesi vazifesini görmüştü ${ }^{2}$. Devletin resmi niteliğindeki bu gazetede; Padişahın Hatt-1

\footnotetext{
' Osmanlı İmparatorluğu'nda, Padişah hatlarının, kanunnamelerin ve bütün kademelerdeki yetkililerin çıkardıkları emirlerin halka ve uygulayacak kimselere duyurulmasına çok itina edilirdi. Bunlar şehirlerde, köylerde münadiler(Bir meseleyi yüksek sesle ilân için resmen görevlendirilmiş kimseler) tarafından meydanda, cami avlularında Devletin emirlerini halka duyururlardı. Sultan II. Mahmut, bu işler için memlekette bir gazetenin çıkarılmasının zaruriyetine inanmış ve bu işi gerçekleştirmek istemişti. Nitekim yayınladığı fermanla "Takvim-i Vekâyi" adıyla bir gazetenin çıkarılmasını istemişti. Hasan Refik Ertuğ, "Resmî Gazete ve Düsturların Tarihi”, Hayat Tarih Mecmuası, Cilt: 1, Sayı: 12, (1 Mayıs 1976), İstanbul, s. 73.

${ }^{2}$ İlk sayısı 11 Kasım 1831'de çıkarılan Takvim-i Vekâyi'nin 4609 numaralı son sayısı 4 Kasım 1922'de yayınlanmıştı. Bkz. Ertuğ, a.g.m., s. 74.
} 
Hümâyûn (İrade-i Seniyye), hükûmet kararları, kanunlar ve devlet işleriyle ilgili tüzük, yönetmelik, talimat ve genelgeler gibi mevzuat yayınlanıyordu.

11 Nisan 1920(1336) tarihli Takvim-i Vekâyi'de de bundan önceki nüshalarında olduğu gibi, yukarıda belirttiğimiz kanunlar, Padişahın İrade-i Seniyyeleri, Hükûmet kararları ve devlet işleriyle ilgili mevzuata ilişkin hukuki düzenlemeler yayınlanmıştı. Ancak "3824" numaralı Takvim-i Vekâyi'de çıkan üç önemli karar Kuva-yı Milliye Hareketi olarak ta isimlendirdiğimiz "Millî Mücadele'mizi” yakından ilgilendirmekteydi.

Takvim-i Vekâyi'nin bu sayısında; Şeyhülislâm Dürrîzâde Abdullah Efendinin Kuva-yı Milliye aleyhindeki "Feteva-yı Şerifesi", Damad Ferid Paşa Hükûmeti'nin "Hükûmet Beyannamesi" ile Damad Ferid Paşayı Sadaret görevine getiren ve 5 Nisan tarihli Takvim-i Vekâyi'de yayınlanmış olan Padişahın "Hatt-1 Hümâyûnu" yer alıyordu.

Bu çalışmamızda Kuva-yı Milliye aleyhindeki bu kararların yayınlanma gerekçeleri, muhtevası ve doğurduğu askerî, siyasî ve sosyal neticeleri ele alınacaktır.

\section{Damad Ferid Paşanın IV. Sadareti Ve İlk İcraatları}

Damat Ferit Paşa, 1 Ekim 1919 tarihinde ayrıldı $\breve{g}_{1}{ }^{3}$ Sadaret görevine, yaklaşık yedi ay sonra 5 Nisan 1920 'de yeniden tayin edildi ${ }^{4}$. Bu tayin ile Damat Ferid Paşa 4 üncü defa hükûmeti kurmakla görevlendiriliyordu'.

Damat Ferid Paşanın yeniden iktidar mevkiine gelmesinde İngilizlerin Salih Paşa hükûmetini düşürmeye yönelik faaliyetleri ile ${ }^{6}$ İstanbul'daki

${ }^{3}$ Damat Ferit Paşanın iktidardan uzak kaldığı bu süre içinde İstanbul'da önce Ali Rıza Paşa ve daha sonra da Salih Paşa Hükûmetleri iş başında bulunmuşlardı.

${ }^{4}$ Aslında Sadaret görevi Damat Ferit Paşaya tevcih edilmeden önce, Padişah Mehmed Vahdeddin tarafından Tevfik Paşaya teklif edilmiş ancak Tevfik Paşa bu görevi kabul etmeyince Damat Ferit Paşa dördüncü defa bu göreve getirilmişti. Bkz. Ali Fuat Türkgeldi, Görüp Işsittiklerim, TTK Basımevi, Ankara 1949, s. 282.

${ }^{5}$ Mütareke Dönemi olarak adlandırılan 1918-1922 yılları arasında beş defa hükûmeti kurmakla görevlendirilmiş bulunan Damat Ferit Paşanın görevde kaldığı süreler şöyledir:

0. Damat Ferit Paşa Hükûmeti : ( 4 Mart-15-16 Mayıs 1919)

0. Damat Ferit Paşa Hükûmeti . ( 19 Mayıs-20 Temmuz 1919)

0. Damat Ferit Paşa Hükûmeti : ( 21 Temmuz-1 Ekim 1919)

0. Damat Ferit Paşa Hükûmeti : ( 5 Nisan-31 Temmuz 1920)

0. Damat Ferit Paşa Hükûmeti : ( 31 Temmuz-17 Ekim 1920).

Bu bilgi için bkz. Nazım Tektaş, Sadrâzamlar-Osmanlı'da İkinci Adam Saltanatı, Çatı Kitaplan, İstanbul 2002, s. 718-730.

${ }^{6}$ İstanbul'da bulunan İtilâf Devletleri Yüksek Komiserleri, ilki 16 Mart 1920'de, ikincisi 26 Mart 1920'de ve üçüncüsü de 29 Mart 1920'de olmak üzere Salih Paşa Hükûmetine arka arkaya verdikleri üç nota ile, Hükûmetten Mustafa Kemal Paşa ile Milliyetçi hareketin diğer 
Kuva-yı Milliye aleyhtarlarının çabaları önemli rol oynamıştı ${ }^{7}$. Bilhassa Kuva-yı Milliye aleyhtarı Peyam-1 Sabah ve Alemdar gibi İstanbul gazetelerinin bu çabalarda önemli rol oynadığı görülüyordu. Öyle ki Peyam-1 Sabah'ta, daha 25 Mart'ta "Sadaret makamının Damat Ferid'e teklif edildiğine" dair yazılar yazılmıştı ${ }^{9}$. Hükûmetin istifa edeceğine ilişkin haberlerin gazetelerde çıkması üzerine Evkâf Nazırı Ömer Hulusi Bey Vakit gazetesine bir demeç vererek "Bir hükûmet buhranının olmadı ğını, herkesin karşı fikirlerini söylemekte ve tahminlerde bulunmakta serbest olduğunu" söylemişti ${ }^{10}$. Maarif Nazırı Abdurrahman Şeref Bey de 2 Nisan'da gazetelerde çıkan demecinde "Hükûmet buhranı hakkında şimdiye kadar çıarılan rivayetlere rağmen mevkilerini muhafaza ettiklerini, hükûmetin kendi namus ve hamiyetinden kuvvet alarak görevini sürdüreceğini” söylüyordu ${ }^{11}$.

yöneticilerinin reddedilmesini istemişlerdi. Bu notalar için bkz. Bilâl N. Şimşir, İngiliz Belgelerinde Atatürk, C. 2, TTK Basımevi, Ankara 1975, s. 8-11. ve Mehmet Tevfik Beyin (Biren) II. Abdülhamit, Meşrutiyet ve Mütareke Devri Hattraları, C. 2, Yay. Haz. F. Rezan Hürmen, Arma Yayınları, İstanbul 1993, s. 375-385. İtilaf Devletleri özellikle İngiltere, İstanbul'un resmen işgalinden sonra iş başında bulunan Salih Paşa Hükûmetini düşürmeye yönelik faaliyetlerini artırdılar. Bu yönde baskı yapmaya başladılar. Nitekim Yüksek Komiserler 26 Mart 1920'de verdikleri ortak bir nota ile hükûmetten Kuva-yı Milliye hareketini resmen red ve mahkûm etmesini istediler. Salih Paşa Hükûmeti bu notaya 29 Mart'ta verdiği cevapta, Anadolu'daki Kuva-yı Milliye namı altında yapılan hareketlerin "meşru hakların müdafaası" olduğu cevabını verdi. Bunun üzerine Yüksek Komiserler 31 Mart'ta bir nota daha vererek aynı isteklerini tekrarladılar Buna karşılık hükûmet 1 Nisan 1920 'de verdiği bir nota ile işgal kuvvetlerinin hukuka aykırı bu muamelelerini protesto etmişti. Adnan Sofuoğlu, Kuva-yı Milliye Döneminde Kuzeybatı Anadolu (1919-1921), Genelkurmay Basımevi, Ankara 1994, s. 324-325. Ayrıca bkz. R Salahi Sonyel, Kurtuluş Savaşı ve Dış Politika, C. I, 2. Baskı, TTK Basımevi, Ankara 1987, s. 209.

${ }^{7}$ İstanbul'da oluşturulan Kuva-yı Milliye aleyhtarı cemiyetler ile İngilizlerin gizli bir plan hazırladıkları ve bu planı tatbike koymak için yoğun bir çabaya giriştikleri görülüyordu. Mart 1920 başlarında hazırlanan bu plana göre; 1-Hükûmet düşürülecek ve Ferit Paşanın başkanlığında veya onun emsali olacak bir kişinin başkanlığında yeni bir hükûmet kurulacaktı. 2-Meclis-i Mebusan fesih edilecekti, 3-Kuva-yı Milliye'nin ilgası sağlanacaktı. 4-İstanbul'da bir şura-yı saltanat teşkil edilecekti.Bu bilgi için Bkz.. Sofuoğlu, age, 1366 no'lu dipnot., s. 366.

${ }^{8}$ Peyam-1 Sabah gazetesi başyazarı Ali Kemal'in bu çabalarda önemli rol oynadığını belirten Yahya Kemal, siyasî ve Edebi Portreler kitabının Ali Kemal'i anlattığı kısmında Damat Ferid Paşanın dördüncü defa sadarete gelişinin tek müsebbibi olarak Ali Kemal-i görmektedir. Kitabında Ali Kemal'in o günlerin İstanbul'undaki nüfuzunu anlatırken şunları söylemektedir: “...kat'i olarak denilebilir ki, Ali Kemal olmasaydı, onun gazetesi İtilâfçılığı tekrar kızıştırmasayd, şevk ve cür'et vermeseydi, Ferid Paşa tekrar iktidara gelemezdi. Ali Kemal ihtirasının ateşiyle, ikinci ve asıl yaman olan Ferid Paşa kabinesini mevki-i iktidara getirmiş yegâne adamdır" Bkz. Yahya Kemal, Siyasî ve Edebi Portreler, Baha Matbaası, İstanbul 1968, s. 89.

${ }^{9}$ Peyam-l Sabah, 25 Mart 1336(1920), Nr. 476/10906.

${ }^{10}$ Bu demeç için bkz. Vakit, 31 Mart 1336(1920), Nr: 8432.

"Vakit, 2 Nisan 1336(1920), Nr: 8434. 
Ancak iç ve dış baskılara daha fazla dayanamayan Salih Paşa Hükûmeti 2 Nisan'da istifa etmek zorunda kalıyordu ${ }^{12}$. Padişahın sadarete Damat Ferit Paşayı görevlendirmesi bekleniliyordu. Damat Ferit Paşanın daha önceki iktidarları esnasında Kuva-yı Milliye aleyhine yaptı̆̆ 1 icraatları bilindiğinden, bu durum İstanbul'da bulunan vatansever kesimlerde endişeye yol açmıștı. Nitekim Meclis-i Mebusan'ın İkinci Başkanı olan Hüseyin Kazım Bey, Damat Ferit Paşanın tekrar sadarete getirilmemesi hususunda Padişahla yaptı̆̆g görüşmeden eli boş dönmüştü ${ }^{13}$. Diğer taraftan Ferid Paşanın sadrazam olmaması için Saray'a ve Meclis'e bir çok yerden telgraflar gönderilmişti ${ }^{14}$. Ancak Padişah, İngilizler nezdinde itimada mazhar olduğuna inandığı Damad Ferid Paşayı sadaret mevkiine getirmeye kararliydi ${ }^{15}$.

Beklenildiği gibi Damat Ferit Paşa, 5 Nisan'da hükûmeti kurmakla görevlendirilmiş ve aynı gün kurduğu hükûmet Padişah tarafından tasdik edilmişti ${ }^{16}$. Yeni hükumetin kuruluşu Kuva-yı

${ }^{12}$ Dahiliye Nazırı Ebubekir Hazım Tepeyran'ın teklifi üzerine Hükûmetin, Mustafa Kemal Paşa ile arkadaşlarını takbih etmemek için istifa ettiğine dair bir zabıt tutulmuş ve bütün kabine üyeleri bunu imzalamışlar ve 2 Nisan 1920'de topluca istifa etmişlerdi. Konuyla ilgili daha fazla bilgi için Bkz.. Ebubekir, Hazım Tepeyran, Belgelerle Kurtuluş Savaşı Anılart, Çağdaş Yay. İstanbul 1982, s.51. Ayrıca Bkz..Gotthard Jaeschke, Türk Kurtuluş Savaşı Kronolojisi, 2. Baskı, TTK Basımevi, Ankara 1989, s. 97; Zeki Arıkan, Kurtuluş Savaşı Günlüğü, C. II, TTK Basımevi, Ankara 1994, s. 463-464.; İsmail Hami Danişmend, İzahlı Osmanlı Tarihi Kronolojisi, C. IV, İstanbul 1972, s. 464.

${ }^{13}$ Hüseyin Kazım Bey hatıralarında bu görüşmeyle ilgili olarak "Ferit Paşanın tekrar mevki-i sadarete getirileceğini işittim. Fakat ihtimal vermedim" şeklinde Padişaha bir söz söylediğini, Padişahın da "Evet, kararımı verdim getireceğim!" dediğini belirtmektedir. Konuşmasının devamında "Ferit Paşanın tekrar mevki-i sadarete getirilmesi, memleket ve makam-1 saltanat için bir felaket olacaktır(...) Yine bir takım ehliyetsiz ve münasebetsiz adamları yanına toplayacak ve istibdat ile iş görmek isteyecektir" dediğini buna karşılık olarak da Padişahın "Ferit Paşayı mevki-i sadarete getirmek kararını verdim ve öyle yapacă̆ım" dediğini söylediğini ve hatta "ben Rum patriğini, Ermeni Patriğini ve Hahambaşını da istersem getiririm” dediğini belirtmektedir. Bkz. Hüseyin Kazım Kadri, Meşrutiyetten Cumhuriyet'e Hattralarım, Haz. İsmail Kara, İletişim Yay,. İstanbul 1991, s. 171-174.

${ }^{14}$ Türkgeldi, age, s. 278, 282.

${ }^{15}$ Mithat Sertoğlu, "Son Osmanlı Padişahı VI. Mehmet Vahideddin”, Hayat Tarih Mecmuast, Y1l: 11, C. 2, Sayı: 7(1 Temmuz 1975), s 66.; Sadaret görevi Damad Ferid Paşaya teklif edilmeden önce Sultan Vahdeddin, Tevfik Paşayı Sadarete getirmek istemişti. Ancak Tevfik Paşa bu görevi kabul etmemişti. İnal, age, s. 2051.

${ }^{16}$ Damat Ferid Paşanın Sadarete getirilmesiyle ilgili Hatt-1 Hümâyûn için Bkz. ATASE Arşivi, Kls. 325, Ds. 129, F.1/1; Takvîm-i Vekâyi, 5 Nisan 1336(1920), Nr.3820, Hatt-1 Hümâyûnun bugünkü dile çevrilmiş metni için bkz. İbnülemin Mahmut Kemal İnal, Son Sadrazamlar, C. 4, 3. Baskı, Dergah Yay. 1982, s. 2040, Galip Kemalî Söylemezoğlu, 30 Senelik Siyasî Hatıralarım (Üçüncü ve Son Cilt) 1918-1922, Ülkü Matbaası, İstanbul 1953, s. 357.; Tevfik Bıyıkoğlu, Trakya'da Millî Mücadele, C.II, 2. bs, TTK Basımevi, Ankara 1987, s. 83-84. 
Milliye aleyhtarı çevrelerde ve İngilizler nezdinde büyük memnuniyet yaratmışt1 ${ }^{17}$.

Özellikle Kuva-yı milliye aleyhtarı basında yeni Hükûmet sevinçle karşılanmıştı. Peyam-1 Sabah'ta Ali Kemal, ele geçen bu fırsatın iyi değerlendirilmesini istiyor ve hükûmetin ılımlı kişilerden oluşması için Sadrazam Damad Ferid Paşaya tavsiyelerde bulunuyordu ${ }^{18}$. Refii Cevad ise, Alemdâr'da yazdığı "Yeni Vaziyet Karşısında" başlıklı yazısında Damat Ferid Paşanın uygulayacağı politikaya işaret ediyor ve "Ferit Paşa Hazretleri, Köprülï Mehmed Paşa kadar şedid, Kuyucu Murad Paşa kadar tasviyekâr, Sokullu Mehmet Paşa kadar durendiş bulunacaklardır..." diyordu $^{19}$.

Damat Ferit Paşanın yeniden hükümet kurmakla görevlendirilmesi Kuvayı Milliye cephesinde ise büyük tepkiler yaratmıștı. Bu hükûmete en büyük tepkilerden birisi Mustafa Kemal Paşadan gelmiştir. Anadolu ve Rumeli Müdafaa-i Hukuk Cemiyeti Heyet-i Temsiliyesi adına yayınladığı tamimde; işgal ve baskı altında bulunan Salih Paşa Hükümetinin, milletin hayati menfaatleri aleyhinde kararlar alması için İtilaf Devletleri tarafından yapılan baskılara daha fazla engel olamadığı için istifa etmek mecburiyetinde kaldığı ve yerine Damat Ferit Paşanın tayin edildiği belirtiliyordu. Tamimde devamla "Htyanet-i vataniyesi sabit olan ve düsman süngüsü ile tavzif edilen Damat Ferit Paşa ve heyetinin hiçbir surette tanınmayacă̆ın tamim

${ }^{17} 5$ Nisan'da İngiliz Yüksek Komiseri Amiral de Robeck, İngiliz Dışşleri Bakanı Lord Gürzon’a gönderdiği raporda "İstanbul'da Damat Ferid Paşanın iktidara geldiğini müjdelercesine bildiriyordu. Bu rapor metni için Bkz.. Bilâl N. Şimşir, Ingiliz Belgelerinde Atatürk, C. 2, TTK Basımevi, Ankara 1975, s. 17.

${ }_{18}$ Peyam-l Sabah, 4 Nisan 1336(1920), Nr. 486/10916; Yeni kabinenin kimlerden oluşması gerektiği konusunda Sadrazam Damad Ferid'e tavsiyelerde bulunan Peyam-1 Sabah'ın başyazan Ali Kemal Beyin, "Kabinede Hürriyet ve İtilâf̧̧ı nazırlar istemediği,. onun fırkacılara karşı olduğu ve kabinenin tarafsız kişilerden oluşmasını istediğini” belirten Refik Halid(Karay) Bey, "Nihayet onun istediği oldu ve Ferit Paşa, Reşit, Fahrettin Beylerle Operatör Cemil ve Kara Sait Paşaları peșine takmış, Babıâli'ye yeni şekilde dahil oldu" demektedir. Refik Halid Karay, Minelbab İlelmihrab( Mütareke Devri Anıları), 2. Baskı, İnkılâp Kitabevi, İstanbul 1992, s. 228-229. Yine Alemdar'da "Nakşı Berab" köşesindeki Aydede imzalı yazılarıyla bilinen Refik Halid Bey de 4 Nisan 1920 tarihli yazısında "Ittthatçılardan hesap sorulmasını kimse önleyemez. Bundan sonra biz söyleyelim bizi dinleyiniz" diyerek, "Hürriyet ve İtilâf Fırkası'nın hükûmeti bütün kuvvetiyle destekleyeceğini” söylemekteydi. Bkz.. Alemdar, 4 Nisan 1336(1920), Nr. 468/1772.

${ }^{19}$ Alemdar, 4 Nisan 1336(1920), Nr. 469/2773. Damat Ferid Paşa tarafından kurulan yeni hükûmetle ilgili gazetelerde çıkan diğer bazı değerlendirmeler için Bkz.. Vakit, 5 Nisan 1336 (1920), Nr. 865 . 
eyleriz" denilmekteydi ${ }^{20}$. Yine Hakimiyet-i Milliye'de yayınlanan bir yazıda "Damad Ferid'in bu ülkeye yararlı değil zararlı olacă̆ı" savunulmuştu" .

Gerek İstanbul'daki vatansever çevrelerin ve gerekse Kuva-yı Milliye cephesinin bu hükûmetten endişe duymaları boşuna değildi. Hükûmet'te, Yunan ordusunun muvaffakiyeti için dua edilmesini isteyen bir Adliye Nazırı ve yine okul kitaplarındaki Türk kelimesini Osmanlı kelimesiyle değiştirtmeye çalışan bir Maarif Nazırı vard1 ${ }^{22}$.

Bu hükümetin kuruluş gayesi bizzatihi Padişahın 5 Nisan tarihli Hatt-1 Hümâyûnu'nda da açık olarak belirtilmişti. Padişah "Ehliyet ve rü'yeti" dolayısıyla Sadrazamlığa tayin ettiği Damad Ferid'den "milliyet namı altında ika edilen iğtişaşatı" önlemesini, bu karışıklığı yaratanlar hakkında gerekli kanuni yaptırımların uygulanmasını ve ülkede asayiş ve huzurun yeniden sağlanmasını" istiyordu ${ }^{23}$. Böylece Padişah, Kuva-yı Milliye'ye karșı yürütülecek politikalar için Hükûmete destek olacağını da ortaya koyuyordu.

Kuva-yı Milliye hareketini ve bu hareketin önde gelen lider kadrosunu yok etmek gayesiyle iş başına gelen Damat Ferit Paşa ve hükûmeti, İngilizler tarafından da desteklenmekteydi ${ }^{24}$. Hatta bu Hükûmetle birlikte Mütarekede ikinci "işbirlikçilik" dönemini başlamıştı diyebiliriz. ${ }^{25}$. Nitekim Damad Ferid Paşa, iktidarının daha ilk günlerinde yani 8 Nisan'da İngiliz Yüksek Komiseri Amiral de Robeck'le görüssmüş, Anadolu'daki milli hareketi yok etmek istediğini söyleyerek, İngilizlerin onaylayacağı bir şekilde çalışmaya söz vermiş ve yapacakları için ondan yardım istemişti $\mathrm{i}^{2{ }^{6}}$. Bu görüşmede;

${ }^{20}$ Tamim 13 Nisan 1336(1920) tarihli Hakimiyet-i Milliye gazetesinde de yayınlanmıştı. Hakimiyet-i Milliye, 13 Nisan 1336(1920), Nr. 21; Tamim için ayrıca Bkz. Atatürk'ün Tamim Telgraf ve Beyannameleri IV, TTK Basımevi, Ankara 1991, s. 298-299.

${ }^{21}$ Hakimiyet-i Milliye, 13 Nisan 1336(1920), Nr. 21.

${ }^{22}$ Zeki Sarıhan, a.g.e, s. 490.

${ }^{23}$ Takvim-i Vekâyi, 2 Nisan 1336(1920), no: 3820; İnal, a.g.e, s. 2051-2052.

${ }^{24}$ Damat Ferit Paşanın kurduğu bu yeni Hükûmet'te görev alan üyelerin çoğu İngilizlerin istediği adamlardan oluşmuştu. Bkz. Osman Özsoy, Saltanat'tan Cumhuriyet'e Giden Yolda Kurtuluş Savaşı'nın Perde Arkası, Aksoy Yayıncılık, İstanbul 1999,s. 296; Damat Ferid Paşa, kendisini, yegâne kurtuluşun İngilizlere hoş görünmek olduğuna inandırmış ve bu inancını Padişaha da aşılamıştı” bu değerlendirme için Bkz. Şefik Okday, Büyükbabam Son Sadrazam Ahmet Tevfik Paşa, İstanbul 1986, s .56.

25 "Sultan Vahdettin, eniştesi olan Damat Ferit Paşayı tekrar sadarete getirdi ve kabine 5 Nisan 1920'de ilân edildi. Böylece mütareke esnasında girişilen ikinci "işbirlikçilik" devri başladı. H. Basri Danışman, Arţ̧ı Diplomat-Son Osmanlı Hariciye Nazırlarından Mustafa Reşit Paşa, Arba Yay. İstanbul 1998, s. 100.

${ }^{26}$ Ingiliz Yüksek Komiseri Amiral Robeck'in bu görüşmeyle ilgili olarak kendi dışişlerine gönderdiği belge için Şimşir, age, C. II, 26-29; Sonyel, a.g.e, C. II. s. 211-212. Damad Ferid Paşanın, "dünyaya İngilizlerin gözlüğüyle baktığını" ifade eden değerlendirme için Bkz.. Murat Bardakçı, Şahbaba (Osmanoğullarının Son Hükümdarı VI. Mehmed Vahideddin'in Hayatı, Hattralart, Özel Mektuplart), Pan Yay. I. bs., İstanbul 1988, s. 437. 
"milliyetçilerin" aleyhinde ferman, beyanname ve fetvaların yayınlanacağı ve bunların uçaklarla Anadolu'ya dağıttırılması için yardımcı olunması, Anzavur'un kumandasında oluşturulacak ve milli hareketi bastıracak olan kuvvetler için silah verilmesi, Hukûmeti tarafından Anadolu'ya ajanlar gönderileceği ve bazı siyasi düşmanlarının tutuklanması" gibi konular ele alınmışt1 ${ }^{27}$.

Damat Ferid Paşa, İngiliz Yüksek Komiseri Amiral de Robeck'le yaptığı bu görüşmenin sonucunda, Anadolu'daki millî hareketi yok etmek konusunda almayı düşündüğü tedbirler ve gerçekleştireceği faaliyetler için İngilizlerin desteğini sağlamış gözüküyordu²8.

İngilizler, Damat Ferid Paşanın, milliyetçi akımlara karşı başarı kazanacağından emin olarak onu desteklemeye karar vermişlerdi. Nitekim, ilk görüşmesinden üç gün sonra Amiral de Robeck'i tekrar ziyaret eden Damad Ferid Paşa, paşalık payesi vererek Balıkesir valiliğine atadığı Ahmet Anzavur'un idaresinde Kuva-yı Milliye'ye karşı girişilen harekat için destek istemiști. Amiral Robeck ise, Anadolu'daki ulusal harekete İngilizlerin faal bir şekilde katılmalarının söz konusu olamayacağını, ancak Anzavur'un kuvvetlerine askerî yardım yapılacağını, "hükûmetin yetkisine karşı hala meydan okumaya devam eden milliyetçilerin bastırılmasında sarf edilecek çabalarda" İngilizlerin her türlü yardımı yapacaklarını söylemişti ${ }^{29}$.

Aslında bütün bu olup bitenler,"Kuva-yı Milliye'ye yönelik bir plan ve proğramın Padişah, Damat Ferid Paşa Hükûmeti ve İngilizler tarafından el birliği ile uygulamaya konulması" demekti" ${ }^{30}$.

${ }^{27}$ Şimșir, age, C. II, s. 26.

${ }^{28} \mathrm{Bkz}$. Sonyel, age, C. I, s. 212.

${ }^{29}$ Amiral De Robeck'in bu görüşmeyle ilgili olarak İngiliz Dışişleri Bakanı Lord Curzon'a gönderdiği raporu için Bkz. Şimşir, age, c.II, s. 29.

${ }^{30}$ Damad Ferid Paşa, ve Hükûmeti, Anadolu'da yeniden otorite tesis etmesi için mutlaka İngilizlerle işbirliği yapmanın gereğine inanıyordu ve bu inancını Padişaha da aşılamıştı. Padişahı İngilizlerin kendisine ve hükûmetine her türlü desteği verecekleri hususunda ikna etmişti. Nitekim Tevfik Paşa ile ilgili bir çalışmada bu konuyla ilgili olarak "Büyükbabam bir çok kez Sultan Vahideddin'e İngilizlere sığınmakla kurtuluşu beklemenin hatalı olduğunu söylemiş ve Damat Ferit Paşanın 'İngilizlerden aldığı sözüne' derece gerçek olduğunu tahkik için Ingiliz komiseriyle görüşmüştü. Ancak İngiliz komiserinden aldığı cevap:"Biz Osmanlı devleti ile harp halindeyiz, nasıl hükûmetinize vaatlerde bulunabiliriz' şeklinde olmuştu. Büyükbabam bu cevabı Padişaha bildirdiğinde, Padişah buna inanmak istemeyerek, 'Bu iş o kadar gizlidir ki, sizden bile saklıyorlar demişti.” Denilerek Damad Ferid Paşa ile İngilizler arasında bir işbirliğinin olduğunu Padişahta teyit etmekteydi. Bkz.. Okday, age, s. 51. Benzer bir anlatımda Damad Ferid Paşanın Sadarete getirilmesinin söz konusu olduğu günlerde Meclis-i Mebusan ikinci başkanı Hüseyin Kazım Bey, Mabeyn Baş Katibi Ali Fuat Beye "Eğer Ferit Paşa İngilizlerden kuvvetli bir söz almış ise, Zât-1 şâhâne kendisini sadarete getirsin, biz de elbirliği ile çalışırız. Fakat böyle bir söz almamış ise kendisinin sadareti memleketçe pek fena tesir hâsıl edeceğinden bunu yapmasın" demişti. Ali Fuat beyin bu 


\section{Kuva-yı Milliye Hareketine Karşı 11 Nisan 1920 (1336) Tarihli Takvim-i Vekâyi'de Yaymlanan Kararlar}

\section{A) Damat Ferid Paşaya Sadaret'in Tevcih Edildiği Padişah Mehmed Vahdeddin'in Hatt-ı Hümâyûnu}

Osmanlı tarihinin belki de en karışık ve en buhranlı günlerinin yaşandığı bir dönemde iktidara gelmiş ve orada ancak yirmi sekiz gün kalabilmiş olan Salih Paşa Hükûmeti'nin 2 Nisan'da istifası üzerine Sadaret görevi Damad Ferid Paşaya verilmişti. Damad Ferid Paşanın Sadaret görevine getirilmesi 5 Nisan 1336 (1920) tarihli Hatt-1 Hümâyûnu ile gerçekleşmişti. Bu hatt-1 hümâyun ve nazırlar listesi 6 Nisan 1920 tarihli Takvim-i Vekâyi'de yayınlanmıştır ${ }^{31}$. Bilahare aynı hatt-ı Hümâyûn 11 Nisan 1336 (1920) tarihli Takvim-i Vekâyi'de tekrar yayınlanmıştır ${ }^{32}$.

Takvim-i Vekâyi'de yayınlanan nazırlar listesine göre Damad Ferid Paşanın dördüncü kabinesi şu isimlerden oluşuyordu:

"Sadrazam ve Hariciye Nazırı Damad Ferid Paşa, Şeyhülislam Dürr̂̂zâde Abdullah Efendi, Harbiye Nezaretine vekâleten ve Bahriye Nezâretine asaleten Ferikândan Beşinci Kolordu Kumandanı esbakı Mehmet Said Paşa, Dahiliye Nezâretine asaleten ve Şura-y1 Devlet Riyasetine Vekâleten Dahiliye Nazır-1 esbakı Reşit Bey, Adliye Nezaretine Mahkeme-i Temyiz İstida Dairesi Reisi Ali Rüşti Efendi, Maarif Nezaretine Hariciye Müsteşarı Fahrettin Bey, Nafıa Nezaretine Doktor Cemil Paşa, Ticaret ve Ziraat Nezaretine Ferikândan Hüseyin Remzi Paşa, Maliye Nezaretine Vekâleten Maliye Müsteşarlığına tayin olunan Bahriye Muhasebecisi Reşad Bey, Evkâf-1 Humâyun Nezaretine Ferikândan Osman Rifat Paşa"

5 Nisan 1336(1920) tarihli bu Hatt-1 Hümâyûn ile Padişah Vahdeddin Damad Ferid Paşayı Sadrazamlığa, Dürrîzâde Abdullah Efendiyi de Şeyhülislamlığa getiriyordu. Hatt-1 Hümâyûna göre Damad Ferid Paşanın sadaret görevine getirilmesi, kendinden önceki Sadrazam Salih Paşa ve hükûmetinin istifası ile söz konusu olmaktaydı. Padişah, Damat Ferid'i devlet yönetmedeki liyakat ve görüşlerinden dolayı bu göreve getirdiğini ${ }^{33}$

sözleri Padişaha naklettiğinde, Padişahın cevabı "evet" olmuştu. Bu anlatım için Bkz.. Türkgeldi, age, s. 260.

${ }^{31}$ Takvîm-i Vekâyi, 6 Nisan 1336(1920), Nr.3820.; ATASE Arşivi, Kls. 325, Ds. 129, F.11. Alemdar, 11 Nisan 1336(1920), Nr.: 475-2779.; Peyam-l Sabah, 11 Nisan 1336(1920), Nr. 493-10923.

${ }^{32}$ Takvim-i Vekâyi, 11 Nisan 1336(1920), Nr. 3824. Bkz. EK: I.

${ }^{33}$ Padişah Mehmet Vahdeddin, Damat Ferid Paşayı ehliyet ve rü'yetine binaen yani liyakat ve devlet yönetimindeki iş bilirliği ve uzak görüşlülüğünden dolayı sadaret'e getirdiğini söylerken, durumun böyle olmadığı bazı devlet adamlarınca biliniyordu. Nitekim Hüseyin Kazım Kadri bu konuda "Padişaha gelince, güzel ve muntazam söz söyler, iyi düşünür ve görür, fakat sonra azm u iradeden tamamıla tecerrüt ederdi. Damat Ferit'in 
ve kurduğu yeni hükûmetini de onayladığını Hatt-1 Hümâyûnunda belirtiyordu.

Hatt-1 Hümâyûnun bundan sonraki muhtevası oldukça ilginçtir. Çünkü devam eden cümlelerde doğrudan Kuva-yı Milliye hareketi suçlanmakta ve bu harekete karşı tedbirler alınması yeni hükûmetten istenilmekteydi.

Hatt-1 Hümâyûn'da Mondros Mütarekesi'nin imzalanmasından sonra ülkenin siyasi durumunun, yavaş yavaş düzelmeye başladığ ${ }_{1}$ bir sırada "milliyet" adı altında yapılan karışıklıklarla tekrar tehlikeli bir vaziyete geldiği ve bu karışıklıklara karşı şimdiye kadar alınmış olan barışçı önlemlerin bir fayda sağlamadığı ve sonuçsuz kaldığı belirtiliyordu.

Padişah, bir isyan hareketi olarak nitelediği bu karışılıkların devam etmesi halinde, ülkenin daha tehlikeli durumlara düşebileceği endişesini taşıdığını işaret ederek, ülkede karışıklıklara yol açan bu olayların ve isyan durumunun düzenleyicisi ve teşvikçisi olan ve isimleri ve faaliyetleri bilinen kişiler hakkında gerekli kanuni işlemlerin yapılmasını, bu isyana aldatılmak suretiyle katılmış olanlar hakkında genel bir af çıkartılmasını istiyordu. Hükûmetten, bütün Osmanlı ülkesinde asayiş ve düzenin yeniden sağlanması için gereken önlemlerin öncelikli olarak ve hızlı bir şekilde alınması da Padişahça yeni hükûmetin yapması gereken bir görev olarak belirtiliyordu. Hükûmetten beklenen diğer bir görev de, halkın yeniden Hilâfet ve Saltanat makamlarına tam bir sadakatle bağlanmasının sağlanması idi.

Padişah Hatt-1 Hümâyûnu'nda, İtilâf Devletleri ile olan ilişkilerin samimi ve güven verici şekilde geliştirilmesini, devletin çıkarları ile milletin hak ve adalete dayalı savunmasına özen gösterilerek, barışın bir an önce gerçekleştirilmesine çaba gösterilmesini de istemekteydi.

Nihayet Padişah, halkın içinde bulunduğu sıkıntılara çare bulunması için her türlü malî ve iktisadî önlemlere başvurulmasını da Damad Ferid Paşaya diğer bir talebi olarak belirtiyordu.

Görüleceği gibi, Hatt-1 Hümâyûn'nda işgallere karşı Türk vatanının bütünlüğü ve millî istiklâlimizi sağlamak için girişilen Kuva-yı Milliye harekâtı bir isyan olarak nitelendirilmekte ve bu hareketin başında bulunan Mustafa Kemal Paşa ve arkadaşları için gerekli kanuni işlemlerin yapılması istenilmekteydi. Padişah Mehmed Vahdeddin, ülkenin Mondros Mütarekesi'nden sonra uğradığı işgalleri, Türk ve Müslüman ahalinin maruz kaldığı haksızlıklar ve zulümleri adeta görmemezlikten gelerek, ülkede huzur ve asayişin var olduğunu söylemekte ve bu huzur ve asayişi

muvaffakiyetsizliği ve cehliyle ve tecrübesizliğiyle her işte heybet $u$ hüsrana uğradığı mükerreren sâbit olmuş ve muhitinden de istifadeye kabiliyet gösteremediği ve padişahı mesuliyetlerine iştirak ettirmekten de hâli kalmadı̆̆ defaatla görülmüş iken, Vahideddin'in yine ona teveccüh ve itimadının azalmaması izahı kabil olmayan bir haldir" demektedir. Bkz.. Hüseyin Kazım Kadri, age, s. 283. 
bozanlarında vatan kurtarma davası ile ortaya atılmış kişiler olduğunu belirtmektedir.

Hatt-1 Hümâyûn'da Padişah, Damad Ferid Paşadan, ülkenin huzur ve asayişini bozan ve " milliyet" davası ile ortaya atılmış olanlar hakkında daha sert ve kesin bir tavır konulmasını ve bunlar hakkında kanuni yollarla işlem yapılmasını istemektedir. Nitekim bir süre sonra başta Mustafa Kemal Paşa olmak üzere Kuva-yı Milliye ileri gelenleri hakkında İstanbul 1 Numaralı Divan-1 Harb-i Örfi'ce soruşturma açılarak, bilâ istisna haklarında idam kararları alınmass ${ }^{34}$, bu isteğin hayata geçirilmesi demekti.

Damad Ferid Paşanın Sadaret mevkiine getirilmesiyle ilgili bu Hatt-1 Hümâyûnda oldukça dikkat çekici ve beklide ibret verici bir ifade olarak da "İtilâf Devletleriyle samimi ilişkilerimizin güven verici bir şekilde kurulmasının" istenmesidir. Samimi ilişki kurulmak istenen bu devletlerin; Mondros Mütarekesi'nden sonra ülkemizi işgal eden, Paris Barış Konferansı ile Londra ve San Remo Konferanslarında ülkemizi nasıl parçalayıp, paylaşacakları hususunda birbirleriyle yarışan ve nihayet devletin payitahtı olan İstanbul'u işgal ederek millî iradenin tecelligâhı olan Meclis-i Mebusanı basan devletler olduğu herhalde unutulmuştu.

Padişah Mehmet Vahdeddin, eniştesi Damad Ferid'e neler yapması gerektiğini bir bir sıralamakta ve Hatt-1 Hümâyûnda bunların kendi talepleri olduğunu da belirtmek suretiyle Hükûmetin bu hususlarda alacağı karar ve tedbirlerle ve yapacağı bütün icraatlarına destek olacağını ilân etmektedir.

Dünya'ya İngilizlerin gözlüğüyle bakan Damad Ferid Paşa,${ }^{35}$ Anadolu'da yeniden otorite tesis edebilmek için mutlaka İngilizlerle işbirliği yapmanın gereğine inanıyordu ve bu inancını Padişaha da aşılamıştı. Padişahı İngilizlerin kendisine ve hükûmetine her türlü desteği verecekleri hususunda ikna etmişti ${ }^{36}$

\footnotetext{
${ }^{34}$ Bu idam kararlarından ilki; Mustafa Kemal Paşa, Kara Vasıf Bey, Ali Fuat Paşa, Alfred Rüstem Bey, Dr. Adnan Adıvar Bey ve Halde Edip Hanım hakkında çıkarılmıştır. İdam kararı ile ilgili İrade-i Seniye için Bkz. Takvim-i Vekâyi, 27 Mayıs 1336(1920), Nr: 3864, Yine aynı mahkeme tarafından ikinci olarak Kavaklı Fevzi Paşa hakkında verilmiştir. Bu karar içinde Bkz. Takvim-i Vekâyi, 30 Mayıs 1336(1920), Nr: 3866.; Yine aynı mahkemece üçüncü olarak Miralay Selahaddin, Miralay Fahreddin, Miralay İsmet, Miralay Bekir Sami ve Miralay Abbas Hilmi Beyler, Yusuf İzzet ve İsmail Fazıl Paşalar ve mebuslardan Celaleddin Arif, Bekir Sami, Hamdullah Suphi, Cami, Hakkı Behiç ve Rıza Nur ve Yusuf Kemal Beyler ile Eskişehir Mutasarnıfı Fatin Bey ve Müftülerden Mustafa Fehmi ve Mehmet Rifat Efendiler hakkında verilmiştir. Bkz. Takvim-i Vekâyi, 21 Haziran 1336(1920), Nr: 3883.

${ }^{35}$ Bardakçı, age, s. 437

${ }^{36}$ Okday, age, s. 105.
} 


\section{B) Damad Ferid Paşa Hükûmetinin Yayınladığı Beyanname}

11 Nisan 1336(1920) tarihli Takvim-i Vekâyi'de yayınlanan ve muhtevası itibarıyla Kuva-yı Milliye harekâtı aleyhinde hükümlerin yer aldığı ikinci belge "Hükûmet Beyannamesi" dir $^{37}$.

Hükûmet beyannamesinin yayınlanmasını iki nedene bağlıyabiliriz. Bunlardan ilki Padişah Mehmet Vahdeddin'in 5 Nisan tarihli Hatt-1 Hümâyûnu'nda yer alan "halkın Padişah ve Halifeye olan sarsılmaz ve zedelenmez olan sadakatlerini daha da güçlendirmek" düşüncesidir. İkincisi ise Damad Ferid Paşanın 8 Nisan'da İstanbul'daki İngiliz Yüksek Komiseri Amiral De Robeck'le yaptığı görüşmede açıkça dile getirdiği “milliyetçiler aleyhinde bir beyanname yayınlama" arzusudur.

"Hükûmetin Beyannamesidir" başlığıyla Takvim-i Vekâyi'de yayınlanan bu beyannamenin daha ilk cümlesinde" Osmanlı Devleti'nin bugün emsali görülmemiş bir tehlike içerisinde olduğu" belirtilerek ve vatanın tehlikede olduğu vurgulanmıştır.

Devletin ve vatanın karşı karşıya kaldığı bu tehlikenin nedeni olarak ta beyannâmede, Birinci Dünya Savaşı gösterilmektedir. Damat Ferid Paşa Hükûmetine göre; bu savaşa millet, bilmeyerek ve istemeyerek sürüklenmiş, savaşta malı ve canıyla büyük fedakârlıklara katlanmış, ancak savaşın sonucunda yenilgiyi kabullenerek yapılan mütareke ile de galip devletlere teslim olmak zorunda kalmıştı. Beyannameyi yayınlayan hükûmete göre uğradığımız bu üzücü neticeyi kabullenmek, akla ve duruma uygun bir kurtuluş yolunu takip etmeliydik

Beyannamede, yukarıda belirtilen akla ve duruma uygun bir kurtuluş çaresini kabullenmeyen bazı kişilerin sadece hırs ve çıkarları uğrunda "Millî Teşkilât" adı altında ülkede yarattıkları fitne ve fesat hareketleri ile siyasi vaziyetimizi son derecede tehlikeli bir duruma getirdiklerinden bahsedilerek bu durumun, zaten savaş yıllarında yapılan her türlü yolsuzluklar ve cinayetlerden derin bir şekilde etkilenmiş olan kutsal vatanımızda yeni yaralar açtığı belirtilmekteydi.

Hükûmete göre, Teşkilât-1 Milliye adı altında ortaya çıkmış olan bu fitne ve fesat hareketlerini ortaya çıkaranların yaptıkları bazı "çirkin olaylar" Avrupa ve Amerika kamuoyunu tamamen aleyhimize çevirmiş ve bunun sonucu olarak ta bu devletler bizimle yapmaya çalıştıkları barış şartlarını

${ }^{37}$ Takvim-i Vekâyi, 11 Nisan 1336 (1920), Nr.: 3824 ve Bkz. EK II. Damad Ferid Paşa Hükûmeti'nin yayınladığı bu beyanname İstanbul gazetelerinde de yayınlanmıştı. Nitekim Alemdar gazetesi 11 Nisan günlü sayısında "Hükûmetin Pek Mühim ve Tarihi Beyannamesi" başlığıyla aynen vermişti. Bkz. Alemdar, 11 Nisan 1336 (1920), Nr.: 475-2779., Peyam-l Sabah, 11 Nisan 1336(1920), Nr. 493-10923. 
ağırlaştırmışlardı. Hatta bu devletler, mütareke şartları gereği İstanbul'u bile geçici olarak askerî işgal altına almışlardı.

Beyannamede, İstanbul'un askeri işgal altına alınmasından sonra isyan başlarının "Hükûmet Merkezi ile Anadolu arasındaki haberleşme ve ilişkileri kesmeye çalışmaları" en büyük vatan hainliği olarak belirtiliyordu.

Damad Ferid Paşa Hükûmetine göre, Millî Teşkilât bir serkeşlik hareketiydi. Bu hareket, "devletin başını gövdesinden ayırmak ve Anadolu'yu istilaya maruz brrakmak" gibi büyük bir felakete zemin hazırlıyordu.. Bu nedenle "yalancı milliyet" davasıyla ortaya atılanlar şahsî ihtiraslarına vatanı ve milleti feda ediyorlardı. Bunun için bu kimseler "Osmanlı Milletinin" en büyük düşmanları idi.

Beyannameye göre; Millî Teşkilât mensupları; anayasayı ve devletin kanunlarını ayaklar altına alarak halktan zorla para topluyorlar, kişileri zorla askere alıyorlard1. Para vermeyen ve askerlik yapmak istemeyenlere ise eziyet ediyorlar ve öldürüyorlardı. Yine bunlar köyleri ve hatta kasabaları basmakta, yakıp yıkmakta ve yağmalamaktaydılar. Bunların yaptığı bütün bu fiiller Allah'ın emirlerine ve İslâm'ın hukukuna karşıydı. Nitekim beyannamenin ekinde bulunan "Fetva-yı Şerife" ile de bu kanıtlanmıştı.

Beyannamede Hükûmet, Osmanlı vatanının karşı karşıya kaldığı her türlü felâketlerin izalesi, nüfus ve kuvvet bakımından uğradığımız zararların giderilmesinin temel politikaları olduğunu bu nedenle her ferdin hayatı ve çalışmalarına değer verdiklerini ve bu nedenle iyilikle ve kan dökmeden amaca ulaşmayı hedef edindiklerini söylemektedir. Ancak devletin ve milletin büyük tehlike içerisinde bulunan hayatını ve geleceğini kurtarmaya çalışan Hükûmetin, yola gelmeyenleri "Şer-i şerif ve kanun-u münif mucibince ve hatt-1 hümayûn ile tebliğ olunan İrade-i Seniyye-i hazret-i Hilafetpenahiye "göre yok etmek için asla geri durmayacağ 1 da beyannamede belirtilen diğer bir husustu.

Damad Ferid Paşa Hükûmeti beyannamenin son kısmında ise, isyan hareketin tertipçileri ve teşvikçileri tarafından gerek kandırılmak ve gerekse tehdit edilerek bu harekete katılanlar ve yaptıklarının sonucunun ne kadar tehlikeli olacağını düşünmeden işbirliği içerisinde olanlara seslenmekteydi. Nitekim beyânnâme ile, Millî Teşkilâta katılan ve işbirliği içerisinde olan bu kişilerin, bir hafta içinde pişmanlıklarını açıklamaları ve padişaha bağlılıklarını gösterdikleri takdirde, Padişah tarafından af edilecekleri ilân ediliyordu. Diğer taraftan isyan hareketinin tertipçileri ve teşvikçileri ve onlarla birlikte hareket etmekte 1 srar eden asilerin "şer'an ve kanunen" yok edileceği belirtiliyordu.

Damat Ferit Paşa ve Hükûmeti, yayınladığı bu beyanname ile İngilizlerin Salih Hulusi Paşa Hükûmetine yaptırtmak isteyip de yaptırtamadığı "Kuvayı Milliye Hareketinin red ve takbih edilmesi" hususundaki taleplerini yerine 
getirmişti. Bilindiği gibi İstanbul'un işgal edildiği 16 Mart 1920 günü İngilizler Salih Paşa Hükûmetine verdikleri bir nota ile "gerek Klikya ve gerekse muhtelif bölgelerde meydana gelen olaylar müessif vakalardaki mesuliyetleri inkâr edilemeyecek bir vaziyet almış olan Mustafa Kemal Paşa ve arkadaşlarının yaptıklarının hükûmet tarafindan red ve takbih edilmesini" istemişlerdi ${ }^{38}$. Salih Paşa Hükûmeti bu notaya 17 Martta verdiği cevapta "Hükûmetinin bu hareket üzerinde bir tesir ve murakabe yapma imkanına sahip olmadığını ve bu hareketi idare edenler tarafından ika ve tatbik edilebilmiş olan aykırı tedbirleri takbih ve tenkit etmekten başka bir şey yapamayacă̆ını" bildirmişti. ${ }^{39}$

İtilaf Devletleri Komiserleri, hükûmetin verdiği bu cevaptan tatmin olmamışlardı. Çünkü onlar hükûmetin "Kuva-yı Milliye'yi kabul etmediklerini ve onu reddettiklerini" açıklamalarını istemişlerdi. Oysa hükûmet ne Kuva-yı Milliye'yi red etmiş ne de Mustafa Kemal Paşa ve arkadaşlarını asi ilân etmişti. Bunun üzerine 26 Mart'ta Salih Paşa Hükûmetine ikinci bir nota veren İtilaf Devletleri Komiserleri "Osmanlt devletinden, Mustafa Kemal Paşa ve Milliyetçi hareketin diğer yöneticilerinin reddedilmesini istemekle görevlendirildiklerini, Sadaretin gönderdiği 17 Mart tarihli cevabi nota ile bu isteklerin ancak bir kusmına tatminkar cevap alabildiklerini, asıl önemli olanı ise Milliyetçi hareketin liderleri hakkında, 16 Mart tarihinden beri Osmanlı Hükûmetinin hiçbir karşı tavır almamıs olması Yüce Konsey'in kararına dayalı olan bu istekleri Yüksek Komiserlerin geri almaya ve yumuşatmaya yetkilerinin olmadi $\breve{g}$, görevleri gereği Osmanlı Hükûmeti'nin gecikmeden Mustafa Kemal Paşa ve söz konusu hareketin diğer yöneticilerini reddettiğini ilân etmesini, hükûmeti bu kararı almaya tekrar davet ettiklerini" bildirmişlerdi ${ }^{40}$.

Hükûmet bu notaya 28 Mart'ta cevap vermiş ve yayınlamayı düşündüğü beyannâme örneğini de gönderilen cevabi yazıya eklemişlerdi ${ }^{31}$. İtilâf devletleri Yüksek Komiserleri, Salih Paşa Hükûmeti’nin yayınlamayı düşündüğü ve bir örneğinin kendilerine gönderildiği bu beyannameyi de beğenmemişler ve 29 Mart'ta üçüncü bir notayı hükûmete vermişlerdi. Bu notalarında Komiserler; "Mustafa Kemal'i ve Hükûmetin iradesine aykırı

\footnotetext{
${ }^{38}$ Söylemezoğlu, age, s. 194; Tepeyran, age, s. 24-26.

${ }^{39}$ Söylemezoğlu, age, s.195-196. Hükûmetin verdiği bu cevaptan komiserlerin, özellikle İngilizlerin memnun olmadığını söyleyen Dahiliye Nazırı Ebubekir Hazım Bey "Komiserlerin gazetelerle ilânını ısrarla istedikleri red ve takbihin hakiki manası, Mustafa Kemal ve arkadaşlarının devlete karşı isyanlarını ilân etmek demekti. Biz bu teklifi kabul etmeyeceklerini bilerek yazıp suretlerini kendilerine gönderdiğimiz beyannamelerle 15 gün sürüncemede bıraktık demektedir. Tepeyran age, s. 48.

${ }^{40}$ Bu nota için Bkz.. Biren, age, s. 375-376; Şimşir, age, C.:II, Belge No: 2, s. 8-9. İtilaf Devletleri, mütemadiyen kendilerini oyalayan Salih Paşayı koyu bir "Kuva-yı Milliyeci" olarak görmekteydiler. Bu değerlendirme için Bkz.. Tarık Mümtaz Göztepe, Sultan Vahideddin Mütareke Gayyasında, Sebil Yay., İstanbul 1969, s. 260.

${ }^{41}$ Bu yazı ve ekindeki beyanname için Bkz.. Biren, age., s. 378; Şimşir, age, C. II, s. 9-10.
} 
hareket eden Millî Hareketin önderlerini açıkça kınayan ve halkı hükûmetin emirlerine uymaya davet eden bir beyannameyi ancak kabul edebileceklerini" bildirmişlerdi.

Salih Paşa Hükûmeti, bu son notaya 1 Nisan'da uzun bir yazıyla cevap vermiş ve iki ayrı beyanname örneğini de bu yazıya ekleyerek Yüksek Komiserlere göndermişti. Osmanlı Hükûmetini bunaltarak istifaya zorlamayı düşünen İtilâf Devletleri, hükûmetin verdiği ve yayınlamayı düşündüğü beyannameyi yine kabul etmemişlerdi. Bunun üzerine 2 Nisan 1920'de hükûmet topluca istifa kararı almış ve istifa etmişti ${ }^{42}$.

Yukarıda da ifade ettiğimiz gibi İngilizlerin ve Kuva-yı Milliye aleyhtarı çevrelerin çabalarıyla Damad Ferid Paşa tekrar Sadaret görevine getirilmişti. İktidara geldiği günlerde Damad Ferid Paşa "Anadolu'daki Milli Hareketi yok etmek için İngilizlerin onaylayacağı bir şekilde çalışacağı” hususunda İngiliz Amirali De Robeck'e söz vermiş ve ondan yardım ve destek talep etmişti. Nitekim bu sözünde duran Damad Ferid Paşa, 11 Nisan'da yayınladığı hükûmet beyannamesi ile "Mustafa Kemal Paşa ve diğer Kuvay1 Milliye önderlerini asi" ilân etmiş ve Millî Hareketi "harekât-1 bagiyane" olarak nitelemiş ve bunların yaptığı faaliyetlerin "Allah'ın emirlerine ve İslâm hukukuna karşı olduğunu" ilan etmiştir.

Beyannamede vatanın gerçekten büyük bir tehlikede olduğu söylenmektedir. Ancak Damad Ferid Paşa Hükûmetine göre bu büyük tehlike, ülkemizin bir baştan diğer başa işgal altında olduğu, işgal altında bulunan bölgelerdeki Türk ve Müslüman ahalinin Yunan ve Ermeniler tarafından "mezalim" derecesinde katledilmeleri, mal ve mülklerinin gasb edilmesi, ırz ve namuslarının haleldar edilmesi değildi. Beyannamede, İşgaller karşısında vatan bütünlügüüü korumak ve millî istiklâlimizi temin etmek için ortaya atılan Kuva-yı Milliye hareketi ve bu hareketin başta Mustafa Kemal Paşa olmak üzere önde gelen yöneticileri Osmanlı Devleti için büyük bir tehlike olarak görülüyordu.

Vatan ve millet uğrunda giriştikleri mücadele uğrunda, sahip oldukları mevkii, makam, rütbe ile diğer bazı imkânlardan vazgeçerek, gerekirse "sine-i millette bir ferd-i mücahid" olan Mustafa Kemal Paşa ve arkadaşlarının "yalnız hırs ve çıkarları" için bir mücadele başlattıklarının ilan edilmesi de cidden düşünülmesi gereken bir durumdu.

Yine beyannâmede ifade edilen ve Milli Teşkilât mensuplarınca yapıldı̆̆ 1 söylenen "bir takım çirkin olaylardan" kastedilen herhalde Maraş, Urfa ve Antep halkının işgalcilere karşı verdiği mücadele olsa gerektir ${ }^{43}$. Vatanını,

\footnotetext{
${ }^{42}$ Tepeyran, age, s. 52 .

${ }^{43}$ Bilindiği gibi Adana, Maraş, Urfa ve Antep'te Fransız işgal kuvvetleri ve onların işbirlikçisi olan Ermenilere karşı bir millî mücadele yürütülmekte idi. Özellikle Ermenilerin, Fransız işgal kuvvetlerine her türlü yardım ve desteği yapmakta, bu vilayetlerdeki Türk halka
} 
canını ve namusunu, Fransız ve işbirlikçi Ermenilere karşı müdafaa için silaha sarılan bu insanların mücadelesinin "bir takım çirkin olaylar" nitelendirilmesi Damad Ferid Paşa ve Hükûmetinin ihanetlerinin hangi noktaya kadar ulaştığını göstermesi bakımından gerçekten ibret vericidir.

Beyannameden anlaşılan bir diğer altı çizilecek hususta "İstanbul'un işgalinin" gerekçesi olarak Mustafa Kemal Paşa ve arkadaşlarının "Milli Teşkilât" adı altında ortaya çıkardıkları fitne ve fesat hareketi olduğunun belirtilmesidir ${ }^{45}$. Oysa bilindiği gibi İstanbul'un işgalinin en önemli sebeplerinden birisi "İtilâf Devletlerinin yeniden İstanbul Hükûmeti üzerinde etkili tesir ve murakabesini sağlamak, diğeri ise bir süre sonra San Remo Konferansında alınan kararları kabul edecek ve uygulayacak teslimiyetçi ve işbirlikçi bir hükûmeti-Damad Ferid Paşa Hükûmeti- iş başına getirmekti ${ }^{46}$.

Beyannamede isyan başları olarak nitelendirilen Mustafa Kemal Paşa ile arkadaşlarının "Hükûmet merkezi ile Anadolu arasındaki haberleşme ${ }^{47}$ ve

karşı, baskı, sindirme, aşağılama, gasp ve katl gibi yollara baş vurmaktalardı. Bu durum bu vilâyetlerde halkın işgallere karşı direnme azmini artırmış ve Fransızlara karşı silahlı bir mücadeleyi başlatmışlardı. Özellikle Maraş'ta halk Fransızlara ve Ermenilere karşı çok şiddetli ve kanlı bir mücadeleye girişmişti. Bu değerlendirme için bkz. Fahir Armaoğlu, "İngiliz Belgelerinde İstanbul'un İşgali” Belleten, C. LXII, Sayı: 234, (Ağustos 1998), Ankara 1999, s. 473-474.

${ }^{44} 1920$ yılının Mart ayı başlarında Avrupa'da yayınlanan bazı gazetelerde Ermenilerin Klikya'da Türkler tarafından katledildikleri ve 15-20 bin civarında Ermeni'nin öldürüldüğüne dair haberler çıkmaya başlamıştı. Bu konu İngiliz başbakanı Lloyd George tarafında Avam kamarasında dile getirilmişti. Ancak bölgeyi işgal eden ve orada olup bitenleri en bilecek olan Fransızların bu katliamlardan haberleri bile. Bkz.. Yahya Akyüz, Türk Kurtuluș Savașı ve Fransız Kamuoyu (1919-1922), II. bs. TTK Basımevi, Ankara 1988, s. 96. İngiliz Başbakanı Lloyd George "Maraş’taki Ermeni katliamlarına karşılık İstanbul'un rehin alınmasını" önermişti. Fransızların Maraş'ta uğradıklanı yenilgi İstanbul'un ikinci kez ve bu defa resmen işgal edilmesine neden olmuştu. Bu değerlendirme için bkz. Kurtuluş Savaşı Döneminde Türk-Fransız Iliş̧kileri 1919-1922, TTK Basımevi, Ankara 1994, s. 64.

${ }^{45}$ İstanbul'daki İngiliz Yüksek Komiseri Sir John De Robeck, 1 Mart'ta Lord Curzon'a gönderdiği gizli yazıda Maraş bölgesindeki Fransız güçlerine saldıran Ulusçu milis gücüne silah ve mermileri Osmanlı savunma Bakanlığı ile Osmanlı kolordu ve tümen komutanlarının sağladığını" bildiriyordu. Salâhi R. Sonyel, Kurtuluş Savaşı Günlerinde Ingiltere Istihbarat Servisi'nin Türkiye'deki Eylemleri, TTK Basımevi, Ankara 1995, s.67. İstanbul'un işgal edilmesinin, Kuva-yı Milliye Hareketi ile Ermeni katliamlarına dayandıran değerlendirme için bkz. Tahsin Ünal, İstanbul'un İşgali 16 Mart 1920, Türk Kültürü, Yıl: IX, Sayı:101,8Mart 1971), Ankara 1971, s. 477(ss. 457-480). Benzer bir değerlendirme için de bkz. Tevfik Bıyıkoğlu, Atatürk Anadolu'da I (1919-1921), İstanbul 1981, s. 129-130.

${ }_{46}$ İstanbul'daki Fransız Yüksek Komiseri Defrance, Fransız Dışişleri Bakanlığına gönderdiği bir raporunda “İstanbul'da Anadolu'daki milliyetçilerle başa çıkabilecek yeni bir hükûmetin kurulması için padişahı desteklemek, bunun içinde önce önde gelen ittihatçı ve milliyetçileri tutuklamayı ve parlamentoyu feshetmeyi” öneriyordu. Bkz. Yavuz, age, s. 6465 .

${ }^{47}$ Mustafa Kemal Paşa tarafından meydana gelebilecek karışıklıklara mani olmak, muhtemel tahriklere ve yanlış anlaşılmalara meydan vermemek için 16 Mart 1920'de 
ilişkileri kesmeye çalışmaları" en büyük vatan hainliği olarak ilan edilmektedir. Gerçektende İstanbul'un işgal edildiği 16 Mart günü Heyet-i Temsiliye adına Mustafa Kemal Paşa tarafından kolordu komutanlıklarına, valilere ve mutasarrıflara çekilen telgraflarla; Heyeti Temsiliyenin bilgi ve muvafakati olmadan hiçbir makam ve memurun İstanbul ile muhabere etmemesi ${ }^{48}$ Telgraf merkezlerine birer subay veya memur görevlendirilerek telgrafların kontrole tabi tutulması istenmiş ${ }^{49}$, İstanbul ile bütün resmî ve hususî telgraf haberleşmeleri ile telgraf memurlarının gizli görüşmeleri yasaklanmışt1 ${ }^{50}$. Yine Heyet-i Temsiliye Riyasetince Ali Fuat Paşa vasıtasıyla birlik komutanlarına verilen bir direktifle "Geyve Boğazı'ndaki demiryolu hatlarının tahrip edilerek ulașımın kesilmesi ve uzun bir süre için demiryolu hatlarına sahip olunabilmesi için Eskişehir, Afyonkarahisar ve Geyve Boğazı civarındaki İngiliz ve diğer İtilaf Devletleri askerlerinin silahlarının alınması" istenmişti ${ }^{51}$. Birinci Kolordu kumandanına çektiği 31 Mart 1920 tarihli bir telgraf yazısında da Mustafa Kemal Paşa "İstanbul'la resmî ve özel her çeşit yazışmaların kesilmesi ve Harbiye Nezareti'nden ve diğer hükûmet dairelerinden herhangi bir şekilde gönderilecek resmî mektupların, zarflarının açılmadan iadesini uygun gördüklerini”" bildirmiştir ${ }^{52}$.

Devlet merkezi olan İstanbul'un işgal edilmesi karşısında Ankara'da Heyet-i Temsiliye adına Mustafa Kemal Paşa tarafından alınan bu tedbirler ne şahsi bir gaye ve ihtiras içindir ne de keyfidir. Vatanın ve milletinin selâmeti uğrunda alınan bazı tedbirlerdir. Nitekim Mustafa Kemal Paşa bu hususta; kolordulara, vilayetlere ve müstakil livalara gönderdiği 17 mart 1920 tarihli telgrafta şunları söylemektedir: "Meclis-i Mebusan dahi dahil olduğu halde bilcümle devâir-i hükûmetle beraber İstanbul İngilizler tarafindan cebren ve resmen işgal edilmiştir. Telgarafhaneler dahi işgal altında bulunduğundan dolayı ne makam-l Hilâfet ve Saltanat ne de sair makâmat-ı resmiyeye maruzatta bulunmak imkânı kalmamıştır. Bu şeraite nazaran Anadolu Dersaadet'le ve makam-l resmiye ile doğrudan muharebeden mahrum kalmıştır. ve muhabere teşebbüsü doğrudoğruya düşmanları karşımıza çıkarmakta olduğundan dolayı gayricaizdir" ${ }^{53}$.

Anadolu'daki bütün mülkî ve askerî makamlar ile Müdafaa-i Hukuk teşkilatlarına bir telgraf çekilmiş ve "bir müddet için dost olsun, düşman olsun, bütün dış dünya ile resmi bağlantıların geçici olarak kesildiği” bildirilmiştir. Genelkurmay askeri Tarih ve Stratejik Etüd başkanlığı, Askeri Tarih Belgeleri Dergisi, Say1: 79, Belge No: 1475.

${ }^{48}$ Harb Tarihi Vesikaları Dergisi, Y11: 6, Sayı: 22, Vesika No: 566.

${ }^{49}$ Belge için bkz. Harb Tarihi Vesikaları Dergisi, Yıl: 6, Sayı. 22, Vesika No: 564.

${ }^{50}$ Harb Tarihi Vesikaları Dergisi, Yıl: 6, Sayı. 22, Vesika No: 567.

${ }^{51}$ Harb Tarihi Vesikaları Dergisi, Y1l: 6, Sayı. 22, Vesika No: 561.

${ }^{52}$ Bu yazı için bkz, Atatürk Ille İlgili Arşiv Belgeleri(1911-1921 Tarihleri Arasına Ait 106 Belge), Başbakanlık Osmanlı Arşivleri Daire Başkanlığı Yay., Ankara 1982, s.198, Belge No: 88 .

${ }^{53}$ Harb Tarihi Vesikaları Dergisi, Y11: 6, Sayı. 22, Vesika No: 568. 
$\mathrm{Bu}$ telgraftan anlaşılacağı gibi Anadolu ile İstanbul arasındaki haberleşme, işgal ile birlikte zaten kesilmiştir. Nitekim İngilizler İstanbul'u işgal ettikleri sırada aldıkları ilk tedbirlerden birisi de "Telgraf ve Telefon Müdiriyet-i Umumiyesi ${ }^{54}$ ile Harbiye Telgrafhanesi' ${ }^{55}{ }^{55}$ işgal etmek olmuştu. Bu nedenle Damat Ferit Paşa Hükûmeti'nin yayınladığı beyannamede belirtilen "İsyan başlarının Hükûmet merkezi ile Anadolu arasındaki haberleşme ve ilişkileri kesmeye kalkışmaları en büyük vatan hainliğidir" suçlaması asılsız ve doğru olmamaktadır.

Hükûmet beyannamesinde "Millî Teşkilât denilen serkeşlik harekâtı" yani Mustafa Kemal Paşa ve arkadaşlarının, işgallere karşı vatanı ve milleti müdafaa için giriştikleri Milli Mücadele harekâtının, "hem devletin başını gövdesinden ayırmak hem de Anadolu'yu korkunç bir istilaya maruz bırakmak felaketini hazırladıkları" suçlaması yapılıyor. Damat Ferit Paşa Hükûmeti'ne göre ülkemiz her halde işgal altında değildi. Akl-1 selim sahibi olan her insan iyi bilmekteydi ki ülke bir baştan bir başa işgal altındaydı. Bu işgaller ve işgalcilerin ve onların işbirlikçilerinin Anadolu'da ve Trakya'da yaptıkları ülkeyi zaten büyük bir felakete sürüklemişti. Bu beyannâmenin yayınlandığı günlerde vatanın her yeri işgal edilmişti. Bundan daha korkuncu ne olabilir di? Her halde ülkenin parçalanarak yok edilmesi idi. Onu da Damat Ferit Paşa Hükûmeti “Sevr Antlaşması'nı” imzalayarak yapmayacak miydı?

Diğer taraftan devletin başını gövdesinden ayırmak hususuna gelince. İstanbul'un resmen işgaliyle ortada bir devlet de kalmamıştı. Nitekim Mustafa Kemal Paşa İstanbul'un işgal edildiği 16 Mart günü bütün komutanlara, vali ve mutasarrıflara, müdafaa-i hukuk cemiyetlerine, belediye başkanlıklarına ve basın derneğine gönderdiği bir bildiride "Nihayet bugün, İstanbul'u zorla işgal etmek suretiyle, Osmanlı Devleti'nin yedi yüz ylllık hayat ve hakimiyetine son verildi" ${ }^{56}$ diyerek işgal ile birlikte Osmanlı Devleti'nin varlığının ve egemenliğinin hukukî manada sona ermiş olduğunu dile getiriyordu. Yine Mustafa Kemal Paşa14 Kolordu Kumandanı Yusuf İzzet Paşa'nın telgrafına verdiği cevabi yazısında " $B u$ vaziyete nazaran İstanbul'da salâhiyet ve hakimiyetini kullanmaya muktedir bir kudret mevcudiyeti elbette kabul edilemez." ${ }^{57}$ diyerek işgalle birlikte İstanbul'da yetki ve egemenliğe sahip bir gücün kalmadığını belirtmişti.

İstanbul'un işgali dolayısı ile "olağanüstü yetkiye haiz bir meclisin Ankara'da toplanması için yeniden bir seçim yapılması hakkında vilayet ve kolordulara yaptığı 19 Mart tarihli bildirisinde de Mustafa Kemal Paşa şunları söylüyordu:

${ }^{54}$ Harb Tarihi Vesikaları Dergisi, Y11: 6, Sayı. 22, Vesika No: 557.

${ }^{55}$ Harb Tarihi Vesikaları Dergisi, Y11: 6, Say1. 22, Vesika No: 558.

${ }^{56}$ Mustafa Kemal Atatürk, Nutuk, C.1,(1919-1920), Yayına Haz. Zeynep Korkmaz, Başbakanlık Basımevi, Ankara 1984, s. 286.

${ }^{57}$ Harb Tarihi Vesikaları Dergisi, Y11: 7, Sayı. 23, Vesika No: 602. 
“Makarr-ı Hilâfet-i İslâmiye ve Payitaht-l saltanat-l Osmaniyenin Düvel-i I'tilâfiye tarafindan resmen işgali kuvve-i teşriiye ve adliye ve icraiyyeden ibaret olan kuva-yl selaseyi devleti muhtel etmis ve bu vaz'iyyet karşısında ifa-yı vazifeye imkân göremediğini hükûmete resmen tebliğ ederek Meclis-i Mebusan dağılmıştır. Şu halde Makam-ı Hilâfet ve Saltanatın masûniyet-i istiklâlini ve Devlet-i Osmaniye'nin tahlisini temin edecek tedabiri teemmül ve tatbik etmek üzere millet tarafindan salahiyet-i fevkaladeye haiz bir meclisin Ankara'da içtimaa daveti..." 58

Görüleceği üzere ortada ne devlet ve ne de onun baş1 kalmıştı. İstanbul'un işgaliyle birlikte devletin, yasama, yürütme ve yargı gücü bozulmuş ve zaafa uğramıştı. Artık Padişahın ve İstanbul Hükümeti'nin siyasî ve idari anlamda kuvvet ve kudreti kalmamıştı.

Beyannamede Millî Teşkilât mensuplarının anayasayı ve devletin kanunlarına aykırı olarak halktan zorla para toplamak ve askere almak, para vermeyenleri ve askerliği kabul etmeyenleri öldürmek, köyleri ve kasabaları basıp, yağmalar yapmakla suçlanmaktaydılar. Beyannâmede bahsedilen bu suçlamalar, bazı bölgelerde Kuva-yı Milliye bünyesinde yer alan çete veya müfreze reisleri ile bazı Kuva-yı Milliye kumandanlarının yaptıkları fiiller dolayısıyla söz konusu olmaktaydı.

Bilindiği gibi Kuva-yı Milliye'yi örgütleyenler daha ziyade terhis edilmiş olan Osmanlı birliklerinin subayları, İzmir'in işgalinden sonra içerilere çekilip direnişe karar veren subaylar ${ }^{59}$ ile İttihat ve Terakki yönetimi döneminde tayin edilen ve milliyetçi ideolojiyi benimsemiş olan kaymakamlar ile mutasarrıflardı. Bunun yanında Ermeni tehciri yada savaş suçlusu olarak aranan ve tutuklanma ihtimali bulunan yöneticilerdi ${ }^{60}$. Kuvay1 Milliye düzenli bir ordu olmadığı için bünyesinde; tümen, alay, tabur ve bölük teşkilâtları yoktu ${ }^{61}$. Kuva-yı Milliye kuvvetleri farklı insan kaynaklarından teşekkül ediyordu. Nitekim bu kuvvetler içinde; dağda gezen eşkıya ve zeybekler, asker kaçakları, hapishaneden çıkarılan mahkumlar ve zanlılar, bir nevi askere alma şeklinde köylerden ve kasabalardan toplanan kimseler, gerçekten millî ve vatanî duygularla, başka bir gaye gözetmeksizin

${ }^{58}$ Harb Tarihi Vesikaları Dergisi, Y11: 4, Sayı. 13, Vesika No: 337; Askeri Tarih Belgeleri Dergisi, Yıl:30, Sayı:79, Belge No:1746, Nutuk, C. 1, s. 288-289; İhsan Ilgar, Türkiye Büyük Millet Meclisi (1920-1998) ve Osmanlı Meclis-i Mebusanı (1877-1920), Genişletilmiş 2. Baskı, Ankara 1998, s. 25-26.

${ }^{59}$ Batı Anadolu'da silahlı millî bir hareketin başlamasını sağlayan ve bu hareketi bir süre yöneten subaylar arasında Miralay Bekir Sami(Günsav), Miralay Kazım (Özalp) ve Miralay Mehmet Şefik (Aker) 'in isimleri ilkler arasındadır. Bunların yanında Urla'da yarbay Kazım, Ayvalık'ta Yarbay Ali (Çetinkaya), Ödemişte Yüzbaşı Tahir, Nazilli'de Binbaşı Hacı Şükrü gibi isimler Kuva-yı Milliye hareketinin öncüleri sayılabilir. Bkz. Alev Çoşkun, Kuvayı Milliye'nin Kuruluşu, Çağdaş Yay. İstanbul 1996, s. 63.

${ }^{60}$ Bu değerlendirme için bkz. Adnan Sofuoğlu, age, s.131.

${ }^{61}$ Enver Behnan Şopolyo, Kuva-yı Milliye Tarihi, Ankara 1957, s.48. 
mücadeleye katılan gönüllü ve adamlarıyla birlikte müfreze oluşturarak mücadeleye katılan mülk sahipleri bulunuyordu ${ }^{62}$. Çeşitli isimlerle anılan Kuva-yı Milliye kuvvetlerinin komutanları ise genelde efeler ve eşkıya reisleri, komitacılar, sivil kumandanlar ve subaylardı ${ }^{63}$. Başlangıçta bu kuvvetlerin ihtiyaçları mahallindeki zenginlerden ve ordunun yardımlarından karşılanıyordu ${ }^{64}$.

Zamanla Kuva-yı Milliye kuvvetlerinin sayıca artması, ihtiyaçlarında artmasına yol açmış ve bu kuvvetlerin ihtiyaçlarının karşılanmasında bazı güçlükler ortaya çıkmaya başlamıştı. Bu durum bazı Kuva-yı Milliye komutanlarını, belirlenmiş usul ve alınmış kararların dışında halktan asker ve yardım toplamaya sevk etmiştir. Bunların bir kısmı özellikle çetecilik ve eşkıyalık yapmış olanlar, köyleri yağmalamaya ve talana başvurmuşlar, halkın malını ve parasını rızasının dışında gasp yoluyla almaya çalışmışlardır ${ }^{65}$. Bu tür hareketler halkı korkutmuş, halkın Kuva-yı Milliye'ye karşı tutumunun olumsuzlaşmasına neden olmuştur ${ }^{66}$. Bu konuda özellikle Demirci Mehmet Efe ile Çerkez Ethem'in faaliyetleri ve halka yaptıkları eziyet ve baskılar Kuva-yı Milliye hanesine yazılmıştı. Demirci

${ }^{62}$ Sebahattin Selek, Anadolu İhtilali, C. 1, İstanbul 1968, s.117., Doğu Ergil, Millî Mücadele'nin Sosyal Tarihi, Ankara 1981, s. 82-83.

${ }^{63}$ Selek, age, s. 119-120.

${ }^{64}$ Sofuoğlu, age, s. 131. Kazım Özalp'ta "Milli alay ve taburların kumandanları halkın ileri gelenlerinden seçiliyordu (...) Kuvvetlerin iaşesi cephe gerilerindeki milli levazım heyetleri tarafından temin ediliyor bu sarfiyat için gereken paralar da Reddi İlhak heyetleri kanalıyla, halktan vergi veya yardım şeklinde toplanıyordu.” demektedir. Kazım Özalp, Millî Mücadele 1919-1922, Türk tarih Kurumu Basımevi, Ankara 1985, s. 73. Kuva-yı Milliye'nin finansmanı halkın katkılarıyla sağlanmıştır. Bu katkılar gönüllü olarak yapılmıştır. Yardımlar genellikle Müdafaa-i Hukuk Cemiyetleri tarafından "aynî ve nakdî" olarak toplanmıştır. depolardan kaçırılan ve muvazzaf ordunun gizlice verdiği silah ve mühimmat ile milisler teçhiz edilmekteydi. Bkz.. Rifat Önsoy, "Millî Mücadele’nin Malî Kaynakları ve Dış Yardımlar", Millî Mücadele Tarihi (Makaleler) Yayına Haz. Berna Türkdoğan, Atatürk Araştırma Merkezi Yay. Ankara 2002, s. 308.

${ }^{65}$ Konuyla ilgili bir anlatımda "Çeteciler maaşlı ve hayvanlı idiler. Gerek kendilerinin ve gerekse hayvanlarının yiyeceklerini de geçtikleri köylerden ve yerlerden sağladıklarından para biriktiriyorlardı. Ayrıca yaptıkları yağma ve tecavüzler de yanlarına kâr kalıyordu" denilmektedir. Rahmi Apak, Yetmişlik Bir Subayın Hatıraları, TTK Basımevi, Ankara 1988, s. 195 .

${ }^{6}$ Mehmet Temel, İsgal Yıllarında İstanbul'un Durumu, Kültür Bakanlığı Yay., Ankara 1998, s. 98. Bu konudaki bir anlatımda da "Kuvâ-yı Milliye teşkilâtının büyük faydalanı yanında teşkilâtın başındakilerin şahsî menfaat, hırs ve bencillikleri, başına buyruk olma istekleri, emir altına girmek istememeleri bazı zararlı hareketlerinin ve olayların sebepleri olarak gösterilebilir. Nitekim halka zaman zaman kötülüklerde bulunmaları, zorla para toplamaları, mal ve mülklerini almaları bu teşkilatı yıpratmaya ve düşmanlarımızın propagandaları ile halkın kin ve nefretini çekebilmişlerdir." Denilmektedir." Bkz.. Ergünöz Akçora, "Millî Mücadele Süresi İçerisinde Kuvâ-yi Milliye hareketinin Doğuşu" Askerî Tarih Bülteni, Genelkurmay Askerî Tarih ve Stratejik Etüt Başkanlığı Yayını, Yıl: 18, Sayı: 34 (Şubat 1993), A 1993, Ankara, s.13. 
Mehmet Efe'nin Isparta havalisine tebliğ ettiği bir beyanname yukarıdaki yargıları doğrulayıcı nitelikte görülmektedir. Bu beyanname şöyledir:

“Üç yüz on (1894), üç yüz on bir (1895), üç yüz on iki (1896), üç yüz on üç (1897), üç yüz on dört (1898) doğumlular bütün silah ve teçhizat ve elbiseleriyle 40 saat içinde şubelerine müracaat edecek, etmedikleri takdirde, tebligata uymadikları anda yakalanarak, mahkeme edilmeksizin idam ederek, evlatlarını birliğine göndermeyen babaları derhâl idam edeceğım ve evlerini yaktıracă̆ım. Bütün millete vatanın kurtuluşu adına Osmanlı Devleti'nin bağımsızlı̆̆ın să̆lamak amacıyla ilân ediyorum. Bundan böyle birliklerinden firar meydana gelmeyecektir. Her kazada tellallar aracılı̆̆ıyla ilân edilecektir. Bu telgraf ayn zamanda şube başkanlıklarına aynen gönderilecektir.

20 Temmuz 1919

Çete Reisi

$$
\text { Demirci Mehmet Efe" } 67
$$

Kuva-yı Milliye kuvvetlerine asker temini için çıkarılan bu tebliğde Demirci Mehmet Efe'nin ifadeleri oldukça sert ve tehditkar olmakla beraber bunun “vatanın kurtuluşu adına ve Osmanlı Devleti'nin bağımsızlığını sağlamak için" yapıldığının açıklanması bu tür davranışların genellikle şahsî ve keyfilik arz etmediğini göstermesi bakımından önemlidir ${ }^{68}$.

Bunun yanında Müdafaa-i Hukukçu ve Kuva-yı Milliye'ci görünen bazı çıkarcılar da bölgelerindeki kişisel nüfuz ve itibarlarını artırmak için Kuvâ-yı Milliye'yi alet olarak kullanmak istemişlerdir. Nitekim Konya Müdafaa-i Hukuk Heyet-i Merkeziyesi'ne seçilen bazı art niyetli ve çıkarcılar, kendilerine verilen yetkileri kötüye kullanmışlardı. Bunlar Kuva-yı Milliye'nin zabitleri ile efradına ve kendilerine oldukça yüksek maaş bağlatmışlardı. Kuva-yı Milliye'ye hizmet etmekle görevli olan bu kişiler ticaretle uğraşmaya başlamışlardı. Bu olaylar halkın dikkatini çekmiş ve Müdafaa-i Hukuk Cemiyeti ile Kuva-yı Milliye'den şikayetçi olmalarına yol açmışt1 ${ }^{69}$.

Millî Mücadele'mizin Kuva-yı Milliye dönemine ait olan bu tarz olaylar ve davranışlar, bu mücadelenin ileri gelenlerince de hoş karşılanmamış,

${ }^{67}$ Askeri Tarih Belgeleri Dergisi, Y11: 51, Say1: 113, s.24-27, Belge No: 4159. Celâl Bayar, Ben de Yazdım, C. VII, s., Süvari Yüzbaşı Ahmed, Türk İstiklâl Harbi Başında Millî Mücadele, Yay. Haz. İsmail Aka, Vehbi Günay, Cahit Telci, İzmir, 1993, s. 91. Demirci Mehmet Efe'nin Denizli, Isparta ve Burdur sancaklarında yaptığı bazı keyfi uygulamalar, baskı ve eziyetler için Bkz.. Nuri Köstüklü, Millî Mücâdele'de Denizli, Isparta ve Burdur Sancakları, Kültür Bakanlığı Yay. Ankara 1990.

${ }^{Q 8}$ Demirci Mehmet Efe'nin, Millî Mücadeleye atıldığı günden itibaren Kuvâ-yı Milliye'nin daha da güçlendiğini belirten Köstüklü “onun tehditkâr ve otoriter davranışları, belki bu günlerde gerekli idi” demektedir. Bkz. Köstüklü, age, s. 137.

${ }^{\oplus}$ Ahmet Avanas, Millî Mücadele'de Konya, Atatürk Araştırma Merkezi Yay., Ankara 1998, s. 67-68. 
bunlar hakkında kovuşturmalar yapılmış ve hatta ağır cezalara maruz bırakılmıştır

Nitekim Mustafa Kemal Paşa Heyet-i Temsiliye namına İzmit, Adapazarı, Bursa, Konya ve Balıkesir Heyet-i Merkeziyelerine gönderdiği bir tamimde şunları söylüyordu: "Kuvayi Milliye'den olduklarını ileri süren bazı kimselerin kendi çıkarlarını sağlamak amacıyla hareket ettiklerini ve baskı yapmak teşebbüsünde bulundukları işitildi. Haksız ve yasa dışı hareketlerin Millî teşkilâtta yeri yoktur. Bu gibiler hakkında Hükûmet'in kanıni işlem yapacağı kesindir."

Bu tarz olayları önlemek amacıyla Batı Anadolu'da toplanan kongrelerde “Kuva-yı Milliye'nin başta asker temini olmak üzere her türlü ihtiyaçlarının temini bir takım esaslara bağlanmıştı ${ }^{71}$.Nihayet bilindiği gibi Kuva-yı Milliye kuvvetlerinin düzenli ordu haline getirilmesiyle bütün bu olaylar ortadan kalkmıştı.

Ancak bu tür olaylar yukarıda ifade ettiğimiz gibi bazı bölgelerde halkın Kuva-yı Milliye'den şikayetçi olmasına imkân vermiş ve bu da bilhassa İstanbul'daki Millî Mücadele karşı olan Hükûmet ve bazı basın organları tarafından Kuva-yı Milliye'nin kötülenmesi için fırsat yaratmış̧ı ${ }^{72}$. Nitekim Alemdar gazetesinde çıkan bir yazıda "Adapazarı, Düzce ve Hendek'te binlerce halkın Kuva-yı Milliye'nin zulmünden bıktığ ve bundan dolayt maddi ve manevi olarak hükûmetin emrine amade olduklart" belirtiliyordu ${ }^{73}$. Aynı gazetede yayınlanan bir diğer yazıda da "Kuva-yı Milliye ile ahali"nin durumuna değiniliyor ve halkın Kuva-yı Milliye'den el âman dediği belirtilerek Kuva-yı Milliyeciler ile ilgili olarak da "Askerde topluyorlar, Bedel-i nakdi-Gümrük resmide" denilerek halkın bunlarla birlikte olmadığ vurgulanmaya çalışılıyordu. ${ }^{74}$ Alemdar gazetesinde "Kuva-yı Milliye'nin Marifetleri" başlığıyla çıkan yazıda ise Millî Mücadele yıpratılmaya çalış1lıyordu $^{75}$. Aslında Alemdar, Peyam-1 Sabah, Türkçe İstanbul gibi Millî

${ }^{70}$ Nutuk, C .3, s. 140, Belge No: 175 .

${ }^{71} \mathrm{Bu}$ konuda geniş bilgi için şu eserlere bakılabilir: Alptekin Müderrisoğlu, Kurtuluş Savaşı'nın Malî Kaynakları, Atatürk Araştırma Merkezi Yay., Ankara 1990.; Mücteba İlgürel, Millî Mücadele'de Balıkesir Kongreleri, Atatürk Araştırma Merkezi Yay., İstanbul 1999, s. İlhan Tekeli-Selim İlkin, Ege'deki Sivil Direniş'ten Kurtuluş Savaşına Geçerken Uşak Heyet-i Merkeziyesi ve Ibrahim (Tahtakılıç) Bey, TTK Basımevi, Ankara 1989,. Balıkesir ve Alaşehir Kongreleri ve Hâcim Muhittin Çarıklı'nın Kuva-yı Milliye Hatıraları 1919-1920, Yay. Haz. Şerafettin Turan, Türk İnkılâp Tarihi Enstitüsü Yay., Ankara 1967.

${ }^{72}$ Biga bölgesi Kuva-yı Milliye önderlerinden Köprülü Hamdi Bey’in, Biga'da millî bir alay teşkil etmek amacıyla ihtiyaç duyulan parayı Biga ve çevresinden toplamaya çalışması, İstanbul Hükümeti taraftarlarınca Kuva-yı Milliye aleyhinde propaganda malzemesi olarak kullanılmıştır. Konuyla ilgili geniş bilgi için Bkz. Uluğ İğdemir, Biga Ayaklanması ve Aznavur Olayları (Günlük Anılar), TTK Basımevi, Ankara 1973, s. 87 vd.

${ }^{73}$ Alemdar, 29 Nisan 1336(1920), Nr:493-2803.

${ }^{74}$ Alemdar, 7 Nisan 1336, Nr.: 471-2782.

${ }^{75}$ Alemdar, 16 Nisan 1336, Nr.: 480-1790. 
Mücadeleye karşı olan gazeteler, hemen hemen her gün Kuva-yı Milliye aleyhtarı haberler ve yazılar yayınlıyorlardı. Bu haber ve yayınları büyük ölçüde abartarak ve çarpitarak veriyorlardı.

Beyannâmenin son kısmında ise Damad Ferid Paşa, Kuva-yı Milliye harekâtını içten çökertecek, parçalayacak ve zayıflatacak planını açıklıyordu. Burada kandırılarak veya korkutularak yani baskı ve zorla Millî harekâta katılmış olanların ve yine bilmeden ve yaptıklarının sonucunun tehlikeli sonuçlar doğuracağını düșünmeden Kuva-yı Milliye'ye katılan ve onlarla birlikte olanların "bir hafta" içinde pişman olduklarını açıkladıkları ve Padişah'a bağlılıklarını gösterdikleri takdirde af edilecekleri belirtiliyordu. Aksi takdirde Kuva-yı Milliyecilerle birlikte hareket eden her kim olursa olsun dinen ve kanunen yok edilecekleri, bunların en ağır cezalara çarptırılacakları ilân ediliyordu.

Damad Ferid Paşa Hükûmetinin yayınladığı beyannâmede yer alan bu af çağrısıyla, Kuva-yı Milliye harekâtına bil vesile ile katılmış olan ancak bağlılıkları zayıf olanlar hedef alınmaktaydı. Bu çağrıdan bilhassa Kuva-yı Milliye kuvvetleri içerisinde yüksek bir oranda varlığı bilinen "çetelerefeler" ile rızası dışında Kuva-yı Milliye kuvvetlerine katılan askerler hedef alınıyordu. Konuyla ilgili olarak yapılan bir propaganda örneğinde şöyle deniliyordu.

“...Sizleri din kardeşlerinize hem de Halife-i Müslimin efendimizin meşru olan hükûmetine karşı silah kullanmaya zorluyorlar. Bu hükûmete kanuna karşı isyandır...

Padişahımız bunları âsî diye ilan etmiş, şeriat fetvasını vermiş...Teslim olacak ahalinin, askerin malı, canı, namusu benim ve hükûmetimin kefaleti altındadır. Bir tek din kardeşimin burnunun kanaması bile "vallahi ve billahi" müsaade olunmayacaktır."76

Damad Ferid Paşa Hükûmeti'nce yayınlanan bu beyanname ve bilahare Şeyhülislâm Dürrîzâde Abdullah Efendinin fetvası Kuva-yı Milliye kuvvetleri arasında sistemli olarak yayılmaya çalışılmış ve böylece millî kuvvetlerden çok sayıda firarların gerçekleşmesi sağlanmıştı. Nitekim yapılan bir propaganda da "Evlatlarım! ...Size Zat-ı Şahanenin selâmını getirdim. Bundan böyle askerlik kalktı. Vergi alınmayacaktır"77 sözleriyle Kuva-yı Milliye kuvvetlerine katılmış askerlerin firar etmesi sağlanmaya çalışılmıştır.

\footnotetext{
${ }^{76}$ Mudurnu mutasarnfının ahaliye hitaben yayınladığı bu beyannâmenin metni için Bkz. Süreyya Şehidoğlu, Millî Mücadele'de Adapazarı-Bolu, Düzce-Hendek ve Yöresi Ayaklanmaları, Ankara 1970, s. 22-24.

${ }^{77}$ Şapolyo, age, s. 76.
} 
Damat Ferit Paşa Hükûmeti tarafından İzmit Mutasarrıflığına tayin edilmiş olan Ahmet Aznavur; Manyas, Ulubat, Kirmasti ve Gönen taraflarında girdiği köy ve kasabalarda halkı camilere ve meydanlara toplayarak "askerliğıin kalktığını, askerlerin başlarını alıp memleketine dönmelerini ya da kendisine katılmalarını" söylüyordu ${ }^{78}$. Eski İzmit Mutasarrıfı ve Muhammedi Tümeni Komutanı imzasıyla Ahmet Aznavur, Biga bölgesindeki bir çetenin reisi olan Kara Hasan'a bir mektup göndererek “...Oralarda da bu melunlarin zorla masum askerleri toplayıp memleketlerine gönderiniz" diyerek ondan Biga bölgesinde Kuva-y1 Milliye'ye katılmış olan askerlerin etki altına alınarak dağıtılmasını istemişti ${ }^{19}$.

Damad Ferid Paşa Hükûmetinin her icraatına destek veren ve mütareke döneminin işbirlikçi bir cemiyeti olarak bilinen Teali-i İslâm Cemiyeti, "Anadolu'nun Muhterem ve Masum Ahalisi" başlı̆̆ıyla yayınladı̆̆ beyannâmesinin son kısminda "Askerler! Bu kadar uyuduğunuz artık yeter, bu zalimlere alet olduğunuz artık kifayet eder. Padişahımız. Halifemiz. Efendimiz Hazretlerinin merhamet ve şevket kucă̆ı size açılmıştır. Hepiniz koşunuz, geliniz dïnya ahret ve saadetini ihraz ediniz: Isşte size ihtar eyliyoruz, Allah'ını, Peygamberini, Padişahın seven bu tarafa gelsin!"\$0 denilerek askerlerin zihinleri bulandırılmaya çalışılmış ve onlardan Kuva-yı Milliye'yi terk etmeleri istenmişti.

19 Mayıs 1920'de Bolu Mutasarrıfı Osman Kadri Bey tarafından yazılan ve halka dağıtılan bir bildiride ise şunlar söyleniyordu:

"Ey Padişaha, dine, devlete beș yüz seneden beri sadakati ile dünyayı hayrette birakmış olan hakiki Müslümanlar.

....Padişahımız bunları asın diye ilân etmiş, Şeriat fetvasıın vermiş her tarafta harekâta başlamak üzere ordular hareket ettirilmiştir.

...Bunların hepsi günahkar değildir. Aldatılmıș olanların kanına girmeyi vicdanımız dinimiz, kabul etmiyor. Padişahımız Halife-i Müslimin efendimiz. de iğfal edilmiş olanları mazur görerek aff-l şahanelerini ilân ettirdiler.... Teslim olacak ahalinin, askerin mall, canı, namusu benim ve hükûmetimin kefaleti altındadır. Bir tek din kardeşimin burnunun kanamasına bile (vallah ve billah) müsaade olunmayacaktır.Bunu cümlemiz taahhüd ediyoruz. Hatta şimdiye kadar bu yolda hareket etmiş olan zabitânı dahi iğfal edilmiş bir din kardeşi, bir kan kardeşi tanıdı̆̆ımız için ne canlarına ne mallarına dokunulmayacaktir.

Divan-ı harbe de tevdii edilmeyecektir..." ${ }^{\prime \prime}$

\footnotetext{
${ }^{78}$ Şevket Süreyya Aydemir, Tek Adam Mustafa Kemal, (1919-1922) C.II, 9. Baskı, Remzi Kitapevi, İstanbul 1983., s. 300.

${ }^{79}$ Nutuk, C. 3, Belge no: 187, s. 149.

${ }^{80}$ ATASE Arşivi, Kls. 525, Ds. 129, F.1-14

${ }^{81}$ Sebahattin Selek, age, 66-68.
} 


\section{C) Şeyhülislâm Dürrîzâde Abdullah Efendi'nin Fetvâsı}

11 Nisan tarihli Takvim-i Vekâyi'de Kuva-yı Milliye aleyhinde yer alan diğer bir karar da Şeyhülislâm Dürrîzâde Abdullah Efendi ${ }^{82}$ tarafından verilen Fetvâ'd ${ }^{83}{ }^{83}$. Bu fetva ${ }^{84}$ birbirini tamamlayan beş fetva olarak çıkartılmıştır ve hepsinin de hareket noktası "Huruc'u alessultan" yani Sultana ve Padişaha karşı ayaklanma hareketidir.

Şeyhülislâm Dürrîzâde Abdullah Efendi'nin çıkardığı ilk fetvada Kuva-yı Milliye, "Kuva-yı Bagiyye" yani eşkıya kuvvetleri olarak vasıflandırılmıştır. Fetvaya göre bazı kötü kimseler-Millî Mücadele'yi başlatanlar ve idare edenler-anlaşarak, birleşerek ve kendilerine elebaşları seçerek, padişahın sadık tebaasını hile ve yalanlarla aldatmakta ve yoldan çıkarmaktaydılar. Bunlar Padişahın emri olmaksızın asker toplamaktadırlar. Yine bunlar görünüşte askeri beslemek ve donatmak bahaneleriyle, gerçekte ise mal toplamak sevdasıyla șeriata uymayan ve kanunlara aykırı olarak haksız ödeme ve vergiler koyuyorlar ve çeşitli baskı ve işkencelerle halkın mal ve eşyalarını zorla alıyor ve yağmalıyorlardı.

Fetvaya göre; bu kötü kişiler yani Kuva-yı Milliye ileri gelenleri, insanlara zulmetmekte ve Padişahın idaresi altındaki bazı köy ve şehirlere saldırarak, buraları tahrip ve yerle bir etmekteydiler. Yine bunlar padişahın sadık tebaasından suçsuz insanları öldürüyorlar ve kan döküyorlardı. Bu kötü kişiler padişah tarafından atanmış bazı dinî, askerî ve sivil memurları görevlerinden atmakta ve yerlerine kendi yandaşlarını atamaktaydılar. Bunlar devletin başını gövdesinden-İstanbul'u Anadolu'dan-ayırarak

${ }^{82}$ Rumeli Kazaskeri Dürrîzâde Mehmet Dürrî Efendi'nin oğlu olan Dürrîzâde Abdullah Efendi, Damat Ferit Paşanın 4 üncü kabinesinde Şeyhülislâmlık görevine atanmıştır. 5 Nisan 1336(1920) de atandığı bu görevi 31 Temmuz 1336 (1920) tarihine kadar sürmüştür. Damad Ferid Paşa Hükûmeti'nin 31 Temmuz'da istifa etmesi üzerine bu görevi sona ermiştir. Millî Mücadele'nin zaferle sonuçlanması üzerine 1922 sonlarına doğru yurt dışına kaçmıș ve daha sonrada Hicaz Emiri Şerif Hüseyin'in yanına gitmiş ve 19232te Hicaz'da vefat etmiştir. Bkz. Abdülkadir Altınsu, Osmanlı Seyhülislâmları, Ankara 1972; s. 264. Sadık Albayrak, Son Devir Osmanlı Ulemast, C. 1, İstanbul 1996, s. 66-67.

${ }^{83}$ Fetvâ'nın metni için Bkz. Takvim-i Vekâyi, 11 Nisan 1336(1920), Nr. 3824 Bkz. EK III; ATASE Arşivi, Kl. 525, Dy. 129, Fr. 1-1; ATASE Arşivi, Kls.486, Ds. 40-2, F. 7-2. Alemdar, 11 Nisan 1336(1920), Nr.: 475-2779., Peyam-l Sabah, 11 Nisan 1336(1920), Nr. 493-10923.

${ }^{84}$ Fetva'nın değişik tanımları yapılmıştır. Kavram olarak fetva, "bir fakîhin kendisine herhangi bir meselede yöneltilen soruya verdiği, hüküm mahiyetini taşımayan cevap" olarak tanımlanmıştır. Murat Akgündüz, Osmanlı Devletinde Şeyhülislâmlık, Beyan yay. İstanbul 2002, s.219.; Yine fetva " dinî ve hukukî bir meselenin hâl ve açıklanması çerçevesinde vaki olan sorunun cevabıdır”. Şeklinde açıklanmıștır. Bkz. Ömer Nasuhi Bilmen, Hukuku İslâmiye ve Islahatı Fıkhıyye Kamusu, C. 1, İstanbul 1967, s. 246. Bir başka tanımda ise fetva "Hukukî ve dinî bir soru hakkında verilen cevap, ulaşılan karar" olarak belirtilmiştir. İsmail Hakkı Uzunçarşılı, Osmanlı Devleti'nin Illmiye Teşkilâtı, Ankara 1965, s.173. Fetva ile ilgili daha geniş bilgi için Bkz. Ali Sarıkoyuncu, Milli Mücadele'de Din Adamlart, C. II, Diyanet İşleri Başkanlığı Yay., Ankara 1997, s. 21-24. 
ulaştırma ve haberleşmeyi kesiyorlar ve buralarda devletin emirlerinin uygulanmasinı engelliyorlardı.

Fetvaya göre "bu kötü kimseler" hükûmet merkezini tek başına bırakarak, halifeliğin yüceliğini zedeletmek ve zayıflatmak suretiyle Halifeye ihanet etmekteydiler. Yine bunlar Padişah'a da itaatsizlik ediyorlar, devletin düzenini ve asayişini bozmak için uydurma ve yalan haberler yayarak halkı fitneye sevk ederek ortalığı karıştırıyorlardı.

Fetvada bütün bunları yapanların elebaşları, yardımcıları ve bunların peşine takılanlar "asi" olarak nitelendiriliyordu.. Fetvanın son kısmında ise "bu asiler, dağılmaları için haklarında çıkan "Yüce Buyruk"tan sonra, inatla hala kötülükler yapmaya devam ederlerse, bunların işledikleri kötülüklerden ülkeyi temizlemek, halka bunların şer ve kötülüklerinden kurtarmak dini yönden gereklidir" deniliyordu.

Birinci fetvanın hüküm kısmında ise, Yukarıda suç ve kötülükleri anlatılan bu asilerin öldürülmelerinin dinen meşru ve farz olduğu belirtiliyordu.

Şeyhülislâm Dürrîzâde'nin yukarıdaki fetvayı tamamlayıcı tarzda çıkardığı ikinci fetvasında ise; "ülkede savaşmaya ve vuruşmaya güç ve kudreti bulunan bütün Müslümanların halife ve Padişah'ın etrafında toplanmaları ve bunlarla mücadele edilmesi ile ilgili yapılacak çağrılara ve yayınlanan emirlere uyarak Kuva-yı Milliyeci denilen "bagi"lerle savaşmalarının" dini bir zorunluluk olduğu açıklanıyordu

Takvim-i Vekâyi'de yayınlanan üçüncü fetvada, Osmanlı Padişahı ve bütün Müslümanların Halifesi olan Mehmet Vahdeddin tarafından görevlendirilen askerlerin, adı geçen isyancılara yani Kuva-yı Milliye'ye karşı savaşmazlarsa ve mücadeleden kaçınırlarsa veya kaçarlarsa büyük suç işlemiş olacakları açıklanıyordu. Fetvanın devamında ise mücadeleden kaçınan veya kaçan bu askerlerin gerek bu dünyada en ağır ceza ile cezalandırılacakları ve gerekse ahrette en büyük azaplara uğrayacakları belirtiliyordu.

Yukarıdaki fetvayı tamamlayan dördüncü fetvada ise, Kuva-yı Milliye ile savaşmak için görevlendirilmiş askerlerin, asileri öldürdükleri takdirde gazi olacakları ve eğer asiler tarafından öldürülürlerse şehitlik mertebesine yükselecekleri açıklanıyordu.

Şeyhülislâm Dürrîzâde Abdullah Efendi'nin çıkardığı son fetva, asilerle yani Kuva-yı Milliyecilerle mücadele etmek ve savaşmak için verilen Yüce emirlere uymayan Müslümanların günahkar ve suçlu sayılacakları ve şeriat yargılarına göre cezalandırılacaklarını ilân ediyordu.

Görüleceği üzere Damad Ferid Paşayı sadarete getiren Mehmet Vahdeddin'in "Hatt-1 Hümâyûnu'nda" ve "Damad Ferid Paşa Hükûmeti 
tarafından yayınlanan "Hükûmet Beyannamesinde" olduğu gibi Şeyhülislâm Dürrîzâde Abdullah Efendinin çıkardığı yukarıdaki fetvalarda da: Kuva-yı Milliye Harekâtı ve bu harekâtın Mustafa Kemal Paşa önderliğindeki lider kadrosu çok ağır ithamlarla suçlanıyorlardı. Fetvalarda Millî Mücadeleyi başlatanlar ve bu harekâtı yönetenler hak-hukuk tanımayan hain, cani, bâgî, şâki, Hilâfet ve Saltanatı yıkmaya teşebbüs eden kişiler oldukları, kişisel çıkarları için zorla halktan vergi aldıkları ve akset topladıkları, Padişahın gönderdiği memurları görevlerinden alarak kendi adamlarını işbaşına getirdikleri, bu arada İstanbul ile bütün bağlantıları kestikleri, huzur ve sükûnu bozmak için de yalan haberler uydurarak karışıklıklara sebep oldukları belirtiliyordu ${ }^{85}$.

Yine bu fetvalarda da Anadolu hareketi padişah'a karşı bir ayaklanma sayılıyor, Kuva-yı Milliye Harekâtı kötüleniyor ve Padişahın sadık tebaasına zulmedenlerin katledilmeleri gerektiği ileri sürülüyordu ${ }^{86^{3}}$.

Damad Ferid Paşanın dördüncü sadaretinde "Kuva-yı Milliye Harekâtı ile Mustafa Kemal Paşa ve arkadaşlarının red ve takbih edilmesine yönelik olarak yayınlanan padişahın Hatt-1 Hümâyûnu, Hükûmetin Beyannamesi ve Dürrîzâde'nin Fetvası" ile Milli Mücadele'nin meşru bir hareket olmadığı ortaya konulmak istenilmiştir. Böylece başta Padişah olmak üzere bütün milletin bu mücadeleye taraftar olmadığı gösterilmek istenilmiştir. Kuva-yı Milliye hareketinin "dine karşı olduğu" ortaya konulmak istenmiş ve özellikle fetvalarla bu desteklenmeye çalışılmıştır ${ }^{87}$.

Bu fetvanın çıkartılmasında kanaatimize göre hem Padişah ve Damat Ferid Paşa'nın şahsında İstanbul Hükûmeti hem de İtilâf Devletleri ve özellikle İngilizlerin etkili olduğunu söyleyebiliriz. Sadece bu fetva değil, yukarıdan beri vermeye çalıştığımız İrade-i Seniyye ve Hükûmet Beyannamesi'nin muhtevaları ve çıkartılış gerekçelerini düşündüğümüzde bundan hem İngilizlerin hem de Saray ve Hükûmetin siyasi ve askeri beklentiler içerisinde oldukları açıktır.

Padişah Mehmet Vahdeddin ile Damat Ferid Paşa,, İstanbul'un ülke genelinde sarsılan otorite ve egemenliğini yeniden tesis etmek amacıyla bu fetva ve beyannamelere başvurmuşlardı. Anadolu'daki Kuva-yı Milliye hareketinin yok edilmesi, halkın bu harekete verdiği desteğin zayıflatılması ilk ele alınan uygulama olmuştu. Bu yapılırken de fetvalarla olaya dini bir meşruluk kazandırılmaya çalışılmış ve "Padişah'a ve onu hükûmetine itaat etmeyenlerin hem Allah'n hem de tarihin lanetine uğrayacakları" 88

\footnotetext{
${ }^{85}$ Sarikoyuncu, age, s. C. II, s.31-32.

${ }^{86}$ Ali Sarıkoyuncu, Atatürk Din ve Din Adamları, Türkiye Diyanet Vakfı Yay., Ankara 2002, s. 177.

${ }^{87}$ Bu değerlendirme için Bkz.. Samih Nafiz Tansu, Iki Devrin Perde Arkası, Anlatan Hüsamettin Ertürk, Sebil Yay. İstanbul 1996, 427.

${ }^{88}$ Alemdar, 30 Nisan 1336(1920), Nr. 494-2804.
} 
propagandası yapılarak halkın saf ve temiz dini duyguları istismar edilmek istenmişti.

Ingilizler ise işgal hareketlerinin başından itibaren, meşru otoriteyi temsil eden Padişah ve İstanbul Hükümeti ile işbirliği yapmayı ve desteklemeyi kendi çıkarları açısından takip edilecek en sağlam yol olarak görmüşlerdi. Bilhassa bu işbirliği ve destek politikası Damad Ferid Paşanın dördüncü sadaretinde had safhaya çıkmıştı

O günleri yaşamış ve bizzat olayların içerisinde bulunmuş bazı siyasi ve askeri şahsiyetlerin fetvanın İngilizlerin baskısıyla çıkarıldı̆̆ına ilişkin iddialarına rastlamaktayız. Nitekim bu tarihte Damad Ferid Paşa Hükûmeti'nde Dahiliye Nazırlığı görevinde bulunan Ahmet Reşit Bey anılarında, "Bu fetvalar, hükûmet üyeleri arasında çok tartışıldı ve bunların meydana getireceği sakıncalar üzerinde duruldu. Ancak Damad Ferid Paşa, "bu mesele üzerinde İngilizlerin ısrar ettiklerini ve bu ısrar karşısında daha fazla direnemeyerek fetvaların i'lân edilmesine söz verdiğini, bu yoldan dönmenin mümkün olmadığını, dönüldüğ̈̈ takdirde kabine'nin İtilâf devletleri katındaki güven ve i'tibârını kaybedeceğini" söylemesi, muhalifleri susturdu" ${ }^{\$ 9}$ demekte ve Fetvanın çıkartılmasında İngilizlerin baskı ve zorlamasının olduğunu belirtmektedir.

Fetvanın İngiliz baskı ve zorlaması sonucu çıkartıldığı konusunda Eşref Edip Bey'de “O sıralarda Ingilizlerin tazyiki artmıştı. Anadolu'da gelişmeye başlayan Milli Kıyama türlü türlü manialar ihdas etmeye uğraşıllyordu. Bu arada Anadolu'daki hareketin gayri meşruiyeti hakkında bir de fetva neşri için çok şiddetli tazyikte bulunuluyordu.Şeyhülislâm, Haydarizâde İbrahim Efendi idi. ${ }^{90}$ Ingilizler hükûmeti tazyik ederek fetva istiyorlardı. Şeyhülislâm bu fetvayı vermeyerek görevinden ayrıldı. Yerine Dürrîzâde Abdullah Efendi geçti. Her arzuya boyun eğebilecek bir insan olan Şeyhülislâm bu fetvaları, işgal kuvvetlerinin haddi aşmış zulüm ve baskıları altında verdi" ${ }^{91}$ diyordu.

Ali Rıza Paşa ve Salih Paşa Hükûmetlerinde Harbiye Nazırlı̆̆ı görevlerini yürüten $^{92}$ ve İstanbul'un işgali üzerine Anadolu'ya geçerek Ankara'ya gelen Fevzi Paşa, 27 Nisan 1920 tarihinde Türkiye Büyük Millet

${ }^{89}$ Ahmet Reşit Rey, Canlı Tarihler, Gördüklerim Yaptıklarım 1890-1922, Yeni Matbaa, İstanbul 1945, s. 284.

${ }^{90}$ Şeyhülislâm Haydarizâde İbrahim Efendi, Salih Hulusi Paşa Hükûmeti'nde Şeyhülislâmlık görevini üstlenmiști. Bkz. Takvim-i Vekâyi, 9 Mart 1336(1920), Nr.: 3796.

${ }^{91}$ Bkz.. Eşref Edip, Sebilürreşad, C. 10, Sayı: 238, s. 202.

${ }^{92}$ Fevzi Paşa (Çakmak), Ali Rıza Paşa kabinesinde Harbiye Nazırlığı görevine, bu görevde bulunan Mersinli Cemal Paşa'nın İtilâf devletleri'nin baskısı ile istifa etmek mecburiyetinde kalması üzerine 3 Şubat 1336(1920) tarihinde atanmıştı. Bilahare Ali Rıza Paşa kabinesinin de 3 Mart 1920'de istifa etmek mecburiyetinde kalıp, yerine 8 Mart 1920 tarihinde kurulan Salih Paşa Hükûmeti'nde tekrar Harbiye Nazırlığı görevine getirilmişti. Bkz. Hayrullah Gök, Mareşal Fevzi Çakmak'ın Askerî ve Siyasî Faaliyetleri (1876-1950), Genelkurmay Askeri Tarih ve Stratejik Etüt Başkanlığı Yay., Ankara 1997, s. 31-32. 
meclisinde yaptığı konuşmada “...Nihayet Padişah Efendimizi de bu tazyik altına koyarak kardeşi kardeşe kırdıracak bir de fetva aldılar",93 diyerek fetvanın çıkartılmasında İngilizlerin baskı ve zorlamasının olduğunu belirtmek istemiştir.

Bu fetvanın bizzat Padişah Mehmet Vahdeddin'in, arzu ve iradesiyle çıkartıldığı hususunda da bazı yaklaşımlar vardır. Osmanlı Sarayında Mabeyn Başkatipliği görevinde bulunan Lütfi Simavi Bey, bu fetvanın özellikle Damad Ferid Paşanın çabası sonucu çıkartıldığı hususundaki düşüncelerini şöyle açıklamaktadır: “...çok yazık ki hâlâ en büyük düşman olarak memleketin karşısında Ferit Paşa göze çarpmaktadır. Bu adamın, artık kinlerini ve cahilliğini bir yana bırakıp, hiç olmazsa bundan sonra bu olumlu gelişmeleri batılılara karşı kullanması gerekirdi. Oysa o-gözünü bürümüss perdenin ardında- Kuva-yı Milliyecileri, güya eski ittihatçılar tarafindan silahlandırılmış bir eşkıya grubu olarak göstermeye çalışıyor, bunların cezalandırılması için şeyhülislâmlara fetvâlar düzenletiyor ve çeteler hazırlıyordu. Zeki olarak bildiğimiz, hiç değilse öyle görmek istediğimiz Sultan vahdettin ise-gerçekten çok yazık ki- eniştesinin elinde daima bir kötülük aracı olmaktan kendini kurtaramad"" 94

Celal Bayar'da “Ingilizlerin destek ve baskılarılya dördüncü defa sadrazamlık koltuğuna oturan Damat Ferit Paşa, Anadolu birliğini içten yıkmak için her türlü tezvire başvurdu. Buna "Emir-i Sultani'ye itaat etmeyen Müslümanlara" ceza tehdidinde bulunan fetvalar da dahildir"95 demek suretiyle Damat Ferid Paşanın fetvanın çıkartılmasında baş rolü oynadığını belirtmektedir.

$\mathrm{Bu}$ konudaki en doğru yaklaşımın, fetvanın İngilizlerin baskısıyla Şeyhülislâmdan alındığı ve çıkartılmasında Damad Ferid Paşanın birinci derecede rol oynadığıdır ${ }^{96}$.

Şeyhülislâm Dürrîzâde Abdullah Efendi tarafından verilen ve Takvim-i Vekâyi'de yayınlanan bu fetva, Millî Mücadele'ye karşı bazı İstanbul gazetelerinde de yayınlanmıştı. Bu gazetelerde çıkan yazılarda fetvaya destek verilmeye çalışılmıştır. Nitekim Peyam-1 Sabah'ta Ali Kemal "Şeriat, Padişah, Adalet" başlıklı yazısında fetvayı savunarak, "yalancı milliyet

${ }^{93}$ Fevzi Paşanın Mecliste yaptığı bu konuşma için Bkz. Türkiye Büyük Millet Meclisi Zabıt Ceridesi, C. 1, s. 92. Fevzi Paşa'nın bu konuşmasının bir özeti Büyük Millet Meclisi kararıyla Reis Mustafa Kemal imzasıyla tamim edilerek bütün yurda duyurulmuştur. Bkz. Harb Tarihi Vesikaları Dergisi, Y11: 4, Sayı. 14, Vesika No: 367-368., Atatürk'ün Tamim, Telgraf ve Beyannameleri IV, TTK Basımevi, Ankara 1991, s. 326-327, Vesika No: 317.

${ }^{94}$ Lütfi Simavi, Baş Mabeynci Lütfi Bey, Osmanlı Sarayının Son Günleri, Hürriyet Yay. İstanbul (ty), s.531.

${ }^{95}$ Celal Bayar, Atatürk'ten Hattralar, Ankara 1955, s. 46.

${ }^{96}$ Sarıkoyuncu, Milli Mücadelede Din Adamları, C.II, s.34. 
davası şer'i şerife aykırıdır" demekteydii ${ }^{97}$. Alemdar gazetesinde çıkan bir yazıda ise, milletin hayatı ile oynanamayacağından bahsedilerek, "Mustafa Kemal'in müstahak olduğu cezayı bulduğu" belirtilerek, çıkartılan fetvaya destek olunmaya çalıșılmıștır ${ }^{98}$.

11 Nisan 133681920) tarihinde Takvim-i Vekâyi'de yayınlanan “Hükûmet Beyannamesi ve Şeyhülislâm Fetvası ve Padişah'ın Hattı Hümayûnu" bir sayfada bir araya getirilerek milyonlarca adette çoğaltılmış ve Anadolu'nun hemen her yerine İngiliz ve Yunan uçaklarıyla atılmışt ${ }^{100}$. Bunun dışında bu beyannâme ve fetvalar posta yoluyla, Anadolu'ya geçen kimseler vasıtasıyla da Anadolu'nun el erişebilen her tarafına ulaştırılmaya çalışılmıştı. Hatta İngiliz Konsolosları, Rum ve Ermeni teşkilâtları bile bu belgelerin Anadolu'ya ulaştırılmasında faal rol oynamışlard $1^{101}$.

Şevket Süreyya Aydemir, Tek Adam Mustafa Kemal isimli eserinde Fetvaların Anadolu'ya duyurulması meselesinde "Yunan uçakları, Halifenin bu kutsal fetvalarını Anadolu göklerine serpiyorlardı. İngiliz torpidoları, İngiliz konsolosları, Rum Ermeni teşkilâtı, Yunan kuvvetleri, Halifenin Müslümanları birbirleri aleyhine kışkırtan fetvalarını Anadolu'ya ulaştırıyorlardı" demektedir ${ }^{102}$.

Bu beyannâme ve fetvaların Anadolu'ya sokulmasında kandırılmış ve ihanete yöneltilmiş kimseler önemli rol oynuyorlard ${ }^{103}$. Nitekim 26 Nisan 1920 'de İstanbul'dan Trabzon'a gelen bir yolcunun üzeri aranmış ve cebinde İstanbul fetvaları, Hatt-1 Hümâyûn ve Hükûmetin beyannamesi bulunmuştu ${ }^{104}$. Bazen de bu görevi Saray'a ve İstanbul Hükûmeti'ne bağlllık içerisinde olan din adamları yapıyordu ${ }^{105}$.

${ }^{97}$ Bkz. Peyam-l Sabah, 11 Nisan 1336(1920), Nr. 493-10923.

${ }^{98}$ Alemdar, 11 Nisan 1336(1920), Nr.475-2779.

99 Milyonlarca adet çoğaltılarak Anadolu'ya değişik yollarla sokulmaya çalışılan bu belge için bkz. EK IV.

${ }^{100}$ Yunus Nadi (Abalıoğlu), Birinci Büyük Millet Meclisi'nin Açılışı ve İç İsyanlar, İstanbul 1955, s. 44-46.; Sebahattin Selek, Anadolu İhtilâli, 5.Baskı, İstanbul 1981, s. 78.; Tarih IV, Kemalist Eğitimin Tarih Dersleri (1931-1941), Kaynak Yay., III. Bs., İstanbul 2001, s. 66 .

${ }^{101}$ Şevket Süreyya Aydemir, Tek Adam Mustafa Kemal(1919-1922), C. II, s. 286.

${ }^{102}$ Şevket Süreyya Aydemir, age, s. 286.

${ }^{103}$ Konuyla ilgili bir anlatımda da "İstanbul fetvaları, doğu illerine de torba torba gönderiliyordu. 29 Nisan 1920 günü Trabzon'a torbalar içinde, İstanbul fetvaları getirilmişti. Bunları, kandırılmış ve ihanete yöneltilmiş kimselerin getirdikleri görülüyordu. Hatta bunların dağıtımının İngilizler tarafından yapıldığı tespit edilmişti. Ele geçirilen bu fetvalar toplatılarak imha ediliyordu" deniliyordu. Bkz.. Hakkı Naşit Uluğ, Siyasi Yönleriyle Kurtuluş Savaşı, Milliyet Yay., İstanbul 1973, s. 208; Hakkı Naşit Uluğ, Hemşehrimiz Atatürk, Türkiye İş Bankası Kültür Yay.,Ankara 1997, s. 136.

${ }^{104}$ Kazım Karabekir, İstiklâl Harbimiz, Merk Yay., İstanbul 1988, s 647.

${ }^{105}$ Cide Müftüsü Hacı Hüseyin Efendi, Limana gelen ecnebi gemisine giderek ve orada eline geçirdiği Şeyhülislâm Dürrîzâde'nin, Kuva-yı Milliye aleyhindeki fetvasını ilçeye 
Diğer taraftan merkezleri İstanbul'da bulunan ve siyasi faaliyetleri bakımından Hürriyet ve İtilaf Fırkasını destekleyen ve Anadolu Hareketi'ne karşı cephe alan Teali İslâm Cemiyeti de $^{106}$ yayınladığı risale ve beyannamelerde "Yunan ordusunun, Hilâfet ordusu olarak addedileceği, Yunan ordusunun zararlı bir teşekkül olmadığı, asıl memlekette kafaları kopartılacak mahlukatın Ankara'da bulunduğu" belirtiliyordu Teali-i İslâm Cemiyeti tarafından yayınlanan bu tür beyanname ve risalelerin yüz binlerce nüshası Eskişehir çevresine kadar Yunan uçakları tarafından atılıyordu ${ }^{107}$.

Teali-i İslâm Cemiyeti'nin yanında Padişah ile Damad Ferid Paşanın Kuva-yı Milliye aleyhine sürdürdükleri mücadelede, Hürriyet ve İtilâf Fırkası, İngiliz Muhipleri Cemiyeti, Askeri Nigehban Cemiyeti, Kızıl Hançerliler Cemiyeti ve Cemiyet-i Ahmediye gibi parti ve cemiyetlerde, Anadolu'daki şubeleri veya Anadolu'ya gönderdikleri elemanları vasıtasıyla destek olmaktaydılar ${ }^{108}$.

Diğer taraftan İngilizler, Hükûmetin yayınladığı beyanname ile özellikle Şeyhülislâm Dürrîzâde'nin fetvalarından oldukça memnun kalmışlardı. Hatta İstanbul'da bulunan İngiliz Yüksek Komiseri Amiral De Robeck, fetvayı tercüme ettirmiş ve bir nüshasını da Londra'ya İngiliz Dışişleri Bakanı Lord Curzon'a göndermişti ${ }^{109}$. Fransızlar ise işgalleri altındaki Adana'da, camilere toplattırdıkları halka, Şeyhülislâmın bu fetvasını okutmuşlard ${ }^{110}$.

getirmiş ve bazı kimselere okumuştu. Kastamonu Valisi Cemal Bey, olaya el atarak Cide Müftüsünü oradan kaçmak zorunda bırakmıştı. Bkz.. Nureddin Peker, Istiklâl Savaşı, Inebolu ve Kastamonu Havalisi, İstanbul 1955, s. 170.

${ }^{106}$ Teali-i İslâm Cemiyeti'nin, siyasi faaliyetleri Hürriyet ve İtilâf Fırkasını desteklemek ve Anadolu Hareketi'ne karşı cephe almak seklindeydi. Konya bölgesinde şubelerde açan bu cemiyetin faaliyetleri Hürriyet ve İtilâf Fırkası taraftarı olan gazeteler tarafından destekleniyordu. Bilhassa Alemdâr Gazetesi bu cemiyetin risale ve beyannamelerine geniş yer veriyordu. Daha Geniş Bilgi için bkz. Tarık Zafer Tunaya, Türkiye'de Siyasi Partiler, Tıpkı Basım(İstanbul 1952, I. Bs) Arba Yay., İstanbul 1995, s. 463. Teali-i İslâm Cemiyeti'nin Millî Mücadelemiz aleyhindeki faaliyetleri için bkz. Ali Sarıkoyuncu, "Şeyhülislâm Mustafa Sabri'nin Milli Mücadele ve Atatürk İnkılâpları Karşıtı Tutum ve Davranışları”, Atatürk Araştırma Merkezi Dergisi, C. XII, Sayı: 39(Kasım 1997), s. 787-812.

${ }^{107}$ Yunus Nadi, Ankara'nın Ilk Günleri, Hisar Matbaası, İstanbul 1955, s. 117-118.

${ }^{108}$ Feridun Kandemir, Istiklâl Savaşı'nda Bozguncular ve Casuslar, İstanbul 1964, s. 9. Bu cemiyetlerle ilgili daha geniş bilgi için bkz. Fethi Tevetoğlu, Millî Mücadele Yıllarındaki Kuruluşlar, TTK Basımevi, Ankara 1988, 55-143; Cengiz Dönmez, Millî Mücadele'ye Karşı Bir Cemiyet: Ingiliz Muhibleri Cemiyeti, Atatürk Araştırma Merkezi Yay., Ankara 1999.; Yücel Özkaya, "Bağımsızlık Savaşında Dernekler, Atatürk Araşsırma Merkezi Dergisi, C. IV, Sayı: 10(Kasım 1987), s. 140-186.

${ }^{109}$ Erol Ulubelen, Íngiliz Belgelerinde Türkiye, İstanbul 1967, s. 272.;İngiltere'de yayınlanan The Times gazetesi 19 Nisan 1920 tarihli nüshasında, fetvanın uçaklarla Anadolu'nun çeşitli şehirlerine atıldığını yazmıştır. Bkz. Osman Özsoy, Gazetecinin İnfazı, Timaş Yay., İstanbul 1997, s. 180.

${ }^{110}$ Kamil Erdaha, Millî Mücadele'de Valiler ve Vilayetler, Yükselen Matbaası, İstanbul 1975, s. 315 . 
Millî Mücadele ileri gelenlerince, memleketin her tarafına bu fetvaların dağılması, yayılması ve bundan doğacak çeşitli tehlikelerin önlenebilmesi için ciddi tedbirler alınmıştı. Ancak bütün alınan tedbirlere rağmen bunların Millî Mücadele'nin etkili olduğu ve halkının Millî Mücadeleye taraftar olduğu bölgelere bile girmesine mani olamamışlard $1^{111}$. Gerek Şeyhülislâmın fetvası ve gerekse Teali-i İslâm Cemiyeti gibi Millî Mücadele karşıtı cemiyetlerce yayınlanan beyannamelerin, yukarıda da belirttiğimiz gibi Anadolu'ya her yolla sokulması ve ülkenin en ücra köșelerine kadar ulaştırılması maksadı hasıl etmiş ve halk üzerinde önemli ölçüde tesir göstermiştir.

Nitekim Kuva-yı Milliye aleyhtarı bazı İstanbul gazetelerinde; Anadolu'nun bir çok bölgesinde Padişah ve Halifeye bağlılık gösterilerinin yapıldı̆̆ı bu gösterilerde, halkın Padişah'a karşı gelen Kuva-yı Milliye harekâtına karşı isyan edeceğine ve gerekirse bunlarla savaşacağına ilişkin açıklamalarda bulundukları ve hatta yemin ettikleri haberleri yayınlanmışt ${ }^{112}$.

Millî Mücadele hareketi ve bu hareketin ileri gelenleri aleyhinde yapılan bu olumsuz propagandaların etkisiyle Anadolu'da halkı büyük bir şaşkınlık ve tereddüt içerisine girmiştir. Bunun sonucunda Anadolu'nun bir çok bölgesinde ayaklanmalar çıkmıştı. Bu ayaklanmalar her geçen gün tehlikeli bir hal almış, Ankara yakınlarına kadar ulaşmıştı ${ }^{113}$. Millî kuvvetlerden çok sayıda asker firarına da yol açan bu gelişmeler, Kuva-yı Milliye önderlerini bu tehlikeli gelişmeleri önleyecek bir takım tedbirlere ve çözüm arayışlarına yönelmiştir.

Bu konuda Ankara'daki Kuva-yı Milliye önderlerini ilk uyaran 56 ncı Fırka Kumandanı Miralay Bekir Sami Bey olmuştu. Bekir Sami Bey 12 Nisan 1920 tarihinde gönderdiği tel yazısında "Dürrîzâde'nin fetvasının İstanbul gazetelerinde yayınlandığını, fetvalarda, Milli Harekete taraftar olanların küfürle itham edildiğini ve "Ĕger bu gece alelacele Ankara vesaire Başmüftileri ve ulema-yı meşhure-i islâmiye tarafindan muktezi mukabil

II' Bayram Sakallı, "Millî Mücadele'de Ankara'da Yayınlanan Fetvanın Millî Birlik ve Beraberliği Sağlamadaki Rolü”, Türk Kültürü Araştırmaları Prof Dr. Şerif Baştav'a Armağan, Y1l: XXV/2, Ankara 1987, s. 198.

${ }^{112}$ Bu haberler için bkz. Alemdar, 13 Nisan 1336(1920), Nr.477-2781, Peyam-ı Sabah, 13 Nisan 1336 (1920), Nr. 495/10925; Alemdar, 15Nisan 1336(1920), Nr. 479-2790, Peyam-l Sabah, 15 Nisan 1336(1920), Nr. 497/10927 Alemdar, 29 Nisan 1336 (1920), Nr. 493-2803, Peyam-t Sabah, 29 Nisan 1336 (1920), Nr. 511/10941.

${ }^{113}$ Mustafa Kemal Paşa bu konuda Nutukta “...dolaylarında alevlenen karışıklık ateşleri, bütün memleketi yakıyor, hainlik, cehalet, kin ve bağnazlık dumanları bütün vatan göklerini yoğun karanlıklar içerisinde bırakıyordu. Isyan dalgaları Ankara'da karargâhımızın duvarlarına kadar çarptı. Karargâhımızla şehir arasındaki telefon ve telgraf hatlarını kesmeye kadar varan kudurmuş̧asına kasıtlar arasında kaldık" demektedir. Bkz. Nutuk, C. II, s.303. 
fetvalar alınmazsa ahvalin Bursa vilayetinde pek ziyade kesb-i vehamet etmesi muhtemeldir" 114 demekte ve acilen tedbir alınmasinı istemekteydi.

Padişah ve Halife'nin esaret altında bulunduğu ve bu nedenle Halifeye zor ve baskı yapılarak böyle bir fetvanın çıkartıldığı düşüncesinden hareketle başta Mustafa Kemal Paşa olmak üzere Kuva-yı Milliye hareketinin dileri gelenlerince, Şeyhülislâm Dürrîzâde'nin fetvasına karşı en etkili tedbirin, yine bir fetva ile alınabileceğine karar verilmişti. ${ }^{115}$

Bunun üzerine Ankara Müftüsü ve Ankara Müdafaa-i Hukuk Cemiyeti Reisi Mehmet Rifat Efendi ${ }^{116}$ başkanlığında yirmi kişiden oluşan bir heyet tarafından $^{117}$ bir fetva hazırlandı. 14 Nisan 1920 tarihinde hazırlanan bu fetva $^{118} 16$ Nisan 1920 'de Mustafa Kemal Paşa tarafından Anadolu'daki diğger müftü ve din adamlarının onayına sunulmak üzere gönderilmiş ve bu konuda mülkî ve askerî yetkililerden yardımcı olmaları da istenmişti. ${ }^{19^{9}}$

Böylece çeşitli vilayetlere gönderilen Ankara'nın fetvası, birçok il ve kaza müftüsü tarafından tasdik edilmiş ve bu durum Ankara'ya telgrafla bildirilmişti. Ankara fetvasını tasdik eden müftülerin isim listesi bilahare İrade-i Milliye gazetesinde ve Hakimiyet-i Milliye gazetelerinde ayr tarihlerde yayınlanmıştı ${ }^{120}$.

Ankara fetvası çalışmamızın çerçevesi dışında kaldı̆̆ hakkında başkaca bir bilgi vermek istemiyoruz. Ancak Ankara Müftüsü Rifat Efendi başkanlığında bir heyetçe çıkartılan ve Anadolu'daki bir çok müftü ve ulema tarafından da tasdik edilen bu fetva ile; Damad Ferid Paşa ve Hükûmeti'nin Şeyhülislâm Dürrîzâde Abdullah Efendiye hazırlattı̆̆ı ve

${ }^{114}$ ATASE Arşivi, Kls.258, Ds. 17-18, F. 7-66/1, Ayrıca bkz. Harb Tarihi Vesikaları Dergisi, Say1: 35, Vesika No: 875 .

115 Günay Çağlar, "Millî Mücadele'de Fetvalar Olayına Değişik Bir Açıdan Bakış", Atatürk Üniversitesi Türkiyat Araştırmaları Enstitüsü Dergisi, 75. Yıl Özel Sayısı, Sayı: 11, Erzurum 1999, s. 267.

116 Ankara Müftüsü Mehmet Rifat Efendi hakkında daha geniş bilgi için bkz. Sarıkoyuncu, Milli Mücadele'de Din Adamlarl, C. I , s. 131-169.

${ }^{117}$ Ankara fetvası olarak bilinen bu fetvayı hazırlayan heyette "Mehmet Rifat Efendi Başkanlığında, Ankara'da bulunan beş müftü, dokuz alim ve medrese müdürü ve altı kişilik ilmiye sınıfından üye olmak üzere" toplam 20 kişi bulunuyordu. Bkz. Bayram Sakallı, Ankara ve Çevresinde Milli Faaliyetler, Kültür ve Turizm Bakanlığı Yay., Ankara 1988, s. 102-103.

${ }^{118}$ ATASE Arşivi, Kls. 525, Ds. 8-129, F. 2. EK V.Ayrıca bkz. Irade-i Milliye, 22 Nisan 1336(1920), Perşembe. EK VI; Hakimiyet-i Milliye, 5 Mayıs 1336(1920), Nr. 27; Alemdar, 5 Mayis 1336 (1920), 499/2809.

${ }^{119}$ ATASE Arşivi, Kls. 299, Ds.13(13 A), F. 20, Ayrıca bkz. Atatürk'ün Tamim Telgraf ve Beyannameleri, C. IV, s. 311, Telgraf No: 211., Karabekir, a.g.e., s. 605.

120 Ankara fetvasını imzalayan müftülerin isimleri önce İrade-i Milliye gazetesinin 22 Nisan 1336 (1920) Perşembe günlü nüshasında yayınlanmıştı. Daha sonra bu fetvalar hakimiyet-i Milliye gazetesinin 5 Mayıs 1336 (1920) tarihli ve 27 numaralı nüshasında yayınlanmıştır (EK VII). 
Anadolu'nun her yerine ulaştırarak Türk halkının zihnini bulandırıp, halkı Millî Mücadele ve bu mücadelenin ileri gelenlerine karşı tavır almaya ve harekete geçmeye yönelik hainane teşebbüsünün zararlı etkileri önemli ölçüde izale edilmişti.

\section{Sonuç}

İstanbul'daki Millî Mücadele karşıtlarının ve özellikle İngilizlerin desteğiyle dördüncü defa Sadrazamlığa getirilen Damad Ferid Paşa, daha önceki iktidarlarında olduğu gibi, bu defa da bütün gayretiyle Kuva-yı Milliye hareketini yok etmeye çalışmıştır.

Padişahın, İstanbul basınının ve her şeyden önemli olan İngilizlerin desteğini arkasına alan Damad Ferid Paşa, Saray ve İstanbul Hükümeti'nin Anadolu'da büyük ölçüde kaybolmuş bulunan otoritesini yeniden sağlamaya çalışmıştır. Bunun için de Türk halkının Millî Mücadele hareketine ve bu hareketin Mustafa Kemal Paşa başkanlığındaki lider kadrosuna duyduğu güven ve bağlılığı zayıflatmayı sağlayacak çabalara girişmiştir.

Halkın Millî Mücadeleye duyduğu güven ve bağlılık zayıflatılmak istenirken de, Milli Mücadele bir eşkiyalık hareketi olarak nitelendirilmiş, onun liderleri de, cani, asi ve aynı zamanda Halifeye ve Padişaha karşı çıkan, Anayasaya ve kanunlara uymayan kişiler olarak suçlandırılmışlardır. Bunun içinde halkın en hassas ve zayıf noktasına hitap edilerek, dini propaganda yoluna başvurulmuştur. Türk Milli Mücadele hareketinin İslâm'a karş1 olduğu noktasından hareket edilerek beyanname ve fetvalar çıkartılmıştır.

Padişahın hatt-1 Hümâyûnu ile Millî Mücadele ileri gelenlerini suçlandırılmış ve böylece Padişah'ında Kuva-yı Milliye harekâtına karşı olduğu gösterilmeye çalışılmıştı.

Hükûmet beyannamesi ile de ülkenin karşı karşıya kaldı̆̆ olumsuzluklardan Kuva-yı Milliye hareketini sorumlu gösterilmiş ve Mustafa Kemal Paşa ve arkadaşlarının Padişah ve Halifeye isyan etmiş kişiler olduğu konusunda kamuoyu oluşturmaya çalışmıştı.

Çıkartılan fetva ile de Anadolu'nun saf ve temiz duygulara sahip Müslüman halkın en zayıf noktasına hitap edilmeye çalışılmıştı. Millî Mücadele hareketini İslâm'a karşı muhalif olarak göstermek amaçlanmış ve tasarlanmıştır. "Padişah ve Halifeye ve onun Hükûmetine itaat etmeyenlerin hem Allah'ın hem de tarihin lanetine uğrayacakları" gibi ifadelerle Kuva-yı Milliye hareketinin meşru olmadığını ortaya koymaya çalışılmış ve bu yapılırken de fetvalarla olaya dini manzara verilmiştir.

$\mathrm{Bu}$ fetva ve beyannameler gerçektende Anadolu halkının zihinlerini bulandırmış, sağlanmaya çalışılan millî birlik ve beraberlik ruhu zedelenmiş ve her tarafta Millî Mücadeleye karşı ayaklanmaların çıkmasına, Kuva-yı Milliye kuvvetlerinden askerlerin firar etmesine ve ihanetlere neden olmuştu. 


\section{KAYNAKLAR}

\section{Arșivler}

Genelkurmay ATASE Başkanlığı Arşivi.

\section{Dergiler}

Askeri Tarih Belgeleri Dergisi.

Harb Tarihi Vesikaları Dergisi.

Sebilürreşad,

\section{Gazeteler}

Alemdar.

Hakimiyet-i Milliye.

Peyam-1 Sabah.

Takvim-i Vekâyi.

Vakit.

\section{Kitaplar}

(Abalıoğlu), Yunus Nadi, Birinci Büyük Millet Meclisi'nin Açıllş̧ ve İç İsyanlar, Hisar Matbaası, İstanbul 1955.

------, Ankara'nn İlk Günleri, Hisar Matbaası, İstanbul 1955.

Akgündüz, Murat, Osmanlı Devletinde Şeyhülislâmlık, Beyan Yay. İstanbul 2002.

Akyüz, Yahya, Türk Kurtuluş Savaşı ve Fransız Kamuoyu(1919-1922), II. bs. TTK Basımevi, Ankara 1988.

Albayrak, Sadık, Son Devir Osmanlı Uleması, C. 1, İstanbul 1996.

Altınsu, Abdülkadir, Osmanlı Şeyhülislâmları, Ankara 1972.

Apak, Rahmi, Yetmişlik Bir Subayın Hattraları, TTK Basımevi, Ankara 1988.

Arıkan, Zeki, Kurtuluş Savaşı Günlüğ̈̈, C. II, TTK Basımevi, Ankara 1994.

Atatürk, Mustafa Kemal, Nutuk, C.1, (1919-1920), Yayına Haz. Zeynep Korkmaz, Başbakanlık Basımevi, Ankara 1984.

Atatürk İle İlgili Arşiv Belgeleri (1911-1921 Tarihleri Arasina Ait 106 Belge), Başbakanlık Osmanlı Arşivleri Daire Başkanlığı Yayını, Ankara 1982.

Atatürk'ün Tamim Telgraf ve Beyannameleri IV, TTK Basımevi, Ankara 1991.

Avanas, Ahmet, Millî Mücadele'de Konya, Atatürk Araştırma Merkezi Yay., Ankara 1998.

Aydemir, Şevket Süreyya, Tek Adam Mustafa Kemal, (1919-1922) C.II, Remzi Kitabevi, İstanbul 1983.

Balıkesir ve Alaşehir Kongreleri ve Hâcim Muhittin Carıklı'nın Kuva-yı Milliye Hatıraları 1919-1920, Yay. Haz. Şerafettin Turan, Türk İnkılâp Tarihi Enstitüsü Yay., Ankara 1967. 


\section{EKLER}

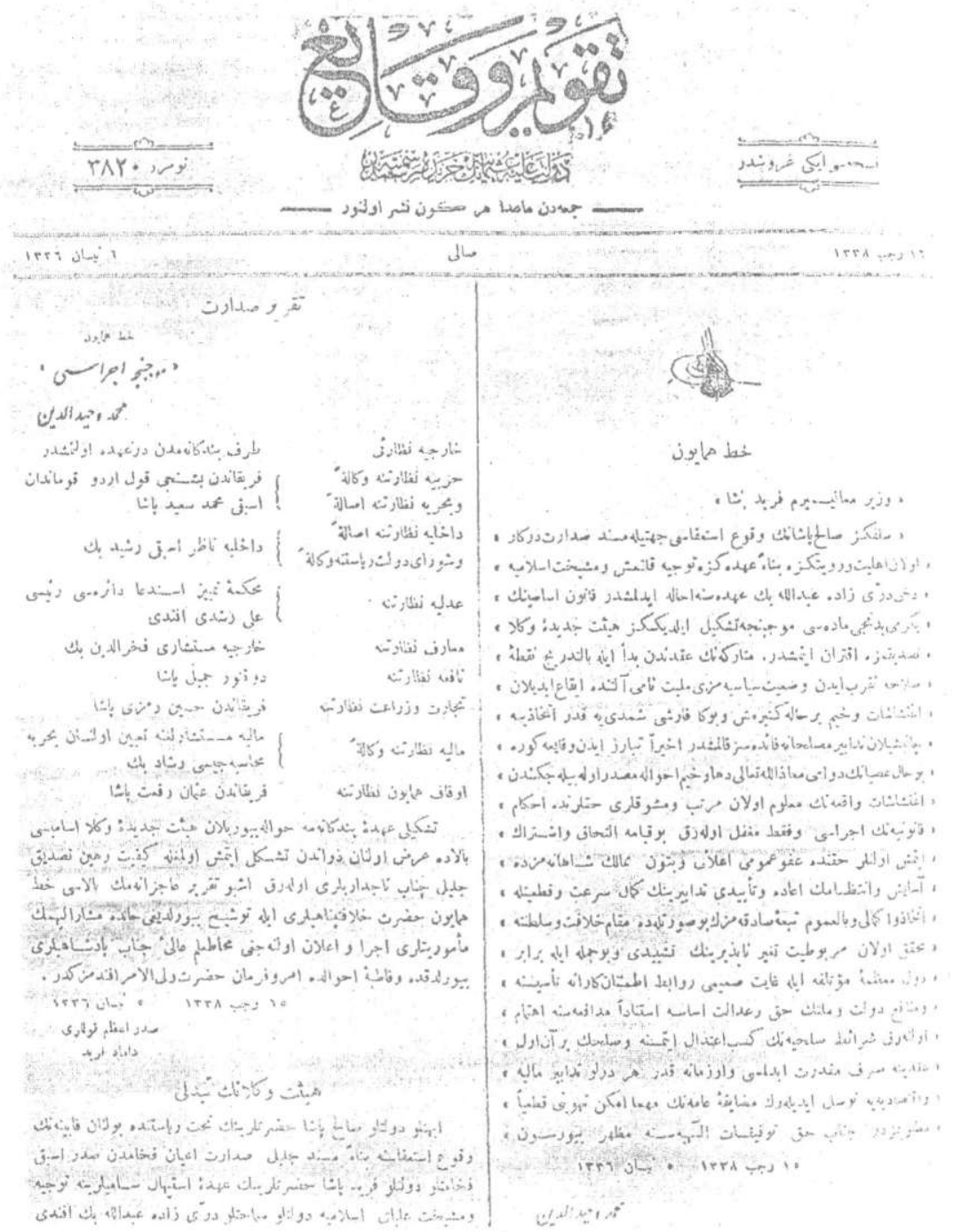

EK 1: Damad Ferid Paşanın Sadarete Getirilmesi İle İlgili Padişah Mehmet Vahdeddin'in Hatt-1 Hümâyûnu. Takvim-i Vekâyi, 11 Nisan 1336 (1920), Nr: 3824. 
Karay, Refik Halid, Minelbab İlelmihrab (Mütareke Devri Anıları), 2. Baskı, İnkılâp Kitabevi, İstanbul 1992.

Köstüklü, Nuri, Millî Mücâdele'de Denizli, Isparta ve Burdur Sancaklart, Kültür Bakanlığı Yay. Ankara 1990.

Mehmet Tevfik Beyin(Biren) II. Abdülhamit, Meşrutiyet ve Mütareke Devri Hatıraları, C.II, Yay. Haz. F. Rezan Hürmen, Arma Yayınları, İstanbul 1993.

Müderrisoğlu, Alptekin, Kurtuluş Savaşı'nın Malî Kaynakları, Atatürk Araştırma Merkezi Yay., Ankara 1990.

Okday, Şefik, Büyükbabam Son Sadrazam Ahmet Tevfik Paşa, İstanbul 1986.

Opr. Dr.Cemil(Paşa) Topuzlu İstanbul Eski Şehremini, İstibdat-MeşrutiyetCumhuriyet Devirlerinde 80 Yıllık Hatıralarım, Haz. Cemalettin Topuzlu, 4. bs., İstanbul 2002.

Önsoy, Rifat, "Millî Mücadele’nin Malî Kaynakları ve Dış Yardımlar”, Millî Mücadele Tarihi(Makaleler) Yay. Haz. Berna Türkdoğan, Atatürk Araştırma Merkezi Yay.Ankara 2002.

Özalp, Kazım, Millî Mücadele 1919-1922, TTK Basımevi, Ankara 1985.

Özsoy, Osman, Saltanat'tan Cumhuriyet'e Giden Yolda Kurtuluş Savaşı'nın Perde Arkast, Aksoy Yayıncilık, İstanbul 1999.

-----, Gazetecinin İnfazı, Timaş Yay., İstanbul 1997.

Peker, Nureddin, İstiklâl Savaşı, İnebolu ve Kastamonu Havalisi, İstanbul 1955.

Rey, Ahmet Reşit, Canlı Tarihler, Gördüklerim Yaptıklarım 1890-1922, Yeni Matbaa, İstanbul 1945.

Sakallı, Bayram, Ankara ve Çevresinde Milli Faaliyetler, Kültür ve Turizm Bakanlığı Yay., Ankara 1988.

Sarıkoyuncu, Ali, Milli Mücadele'de Din Adamları, C. II, Diyanet İşleri Başkanlığı Yay., Ankara 1997.

------, Atatürk Din ve Din Adamları, Türkiye Diyanet Vakfı Yay., Ankara 2002.

Selek, Sebahattin, Anadolu İhtilali, C. 1, İstanbul 1968.

Simavi, Lütfi, Baş Mabeynci Lütfi Bey, Osmanlı Sarayının Son Günleri, Hürriyet Yay. İstanbul (ty), s.531.

Sofuoğlu, Adnan, Kuva-yı Milliye Döneminde Kuzeybatı Anadolu (1919-1921), Genelkurmay Basımevi, Ankara 1994.

Sonyel, R. Salahi, Kurtuluş Savaşı ve Dış Politika, C. I, 2. Baskı, TTK Basımevi, Ankara 1987.

, Kurtuluş Savaşı Günlerinde İngiltere İstihbarat Servisi'nin Türkiye'deki Eylemleri, TTK Basımevi, Ankara 1995.

Söylemezoğlu, Galip Kemalî, 30 Senelik Siyasî Hatıralarım (Üçüncü ve Son Cilt) 1918-1922, Ülkü Matbaası, İstanbul 1953. 
Süvari Yüzbaşı Ahmed, Türk İstiklâl Harbi Başında Millî Mücadele, Yay. Haz. İsmail Aka, Vehbi Günay, Cahit Telci, İzmir 1993.

Şehidoğlu, Süreyya, Millî Mücadele'de Adapazarı-Bolu, Düzce-Hendek ve Yöresi Ayaklanmaları, Ankara 1970.

Şopolyo, Enver Behnan, Kuva-yı Milliye Tarihi, Ankara 1957.

Şimşir, Bilâl N., Ingiliz, Belgelerinde Atatürk, C. 2, TTK Basımevi, Ankara 1975.

Tansu, Samih Nafiz, İki Devrin Perde Arkası, Anlatan Hüsamettin Ertürk, Sebil Yay. İstanbul 1996.

Tekeli, İlhan- İlkin, Selim, Ege'deki Sivil Direniș'ten Kurtuluş Savașına Geçerken Uşak Heyet-i Merkeziyesi ve Íbrahim(Tahtakılıç) Bey, TTKBasımevi, Ankara 1989.

Tektaş, Nazım, Sadrâzamlar-Osmanlı'da İkinci Adam Saltanatı, Çatı Kitapları, İstanbul 2002.

Temel, Mehmet, Issgal Yıllarında İstanbul'un Durumu, Kültür Bakanlığı Yay., Ankara 1998.

Tepeyran, Ebubekir Hazım, Belgelerle Kurtuluş Savaşı Anıları, Çağdaş Yay. İstanbul 1982.

Tevetoğlu, Fethi, Millî Mücadele Yıllarındaki Kuruluşlar, TTK Basımevi, Ankara 1988.

Tunaya Tarık Zafer, Türkiye'de Siyasi Partiler, Tıpkı Basım(İstanbul 1952, I. Bs) Arba Yay., İstanbul 1995.

Türkgeldí, Ali Fuat, Görüp İşittiklerim, TTK Basımevi, Ankara 1949.

Ulubelen, Erol, Ingiliz Belgelerinde Türkiye, İstanbul 1967.

Uluğ, Hakkı Naşit, Siyasi Yönleriyle Kurtuluş Savaşı, Milliyet Yay., İstanbul 1973.

------, Hemşehrimiz Atatürk, 3. baskı,Türkiye İş Bankası Kültür Yay., Ankara 1997.

Uzunçarşılı, İsmail Hakkı, Osmanlı Devleti'nin İlmiye Teşkilâtı, TTK Basımevi, Ankara 1965.

Yavuz, Bige, Kurtuluş Savaşı Döneminde Türk-Fransız İlişkileri 1919-1922, TTK Basımevi, Ankara 1994.

\section{Makaleler}

Akçora, Ergünöz, "Millî Mücadele Süresi İçerisinde Kuvâ-yi Milliye hareketinin Doğuşu" Askerî Tarih Bülteni, Genelkurmay Askerî Tarih ve Stratejik Etüt Başkanlığı Yayını, Yıl: 18, Sayı:34(Şubat 1993), Ankara 1993, s.1-15.

Armaoğlu, Fahir, "İngiliz Belgelerinde İstanbul'un İşgali” Belleten, Cilt: LXII, Sayı: 234, (Ağustos 1998), , Ankara 1999, s. 467-494.

Çağlar, Günay "Millî Mücadele’de Fetvalar Olayına Değişik Bir Açıdan Bakış", Atatürk Üniversitesi Türkiyat Araştırmaları Enstitüsü Dergisi, 75. Yıl Özel Saylsı, Say1: 11, Erzurum 1999, s. 265-282. 
Ertuğ, Hasan Refik, "Resmî Gazete ve Düsturların Tarihi", Hayat Tarih Mecmuast, Cilt: 1, Sayı: 12, (1 Mayıs 1976), İstanbul, s 73-77.

Özkaya, Yücel, "Bağımsızlık Savaşında Dernekler, Atatürk Araştırma Merkezi Dergisi, C. IV, Sayı: 10(Kasım 1987), s.140-186.

Sakallı, Bayram, "Millî Mücadele'de Ankara'da Yayınlanan Fetvanın Millî Birlik ve Beraberliği Sağlamadaki Rolü”, Türk Kültürü Araştırmaları Prof Dr. Şerif Baştav'a Armağan, Yll: XXV/2, Ankara 1987, s. 195-208.

Sarıkoyuncu, Ali, “Şeyhülislâm Mustafa Sabri’nin Milli Mücadele ve Atatürk İnkılâpları Karşıtı Tutum ve Davranışları”, Atatürk Araştırma Merkezi Dergisi, C. XII, Sayı: 39 (Kasım 1997), s. 787-812.

Sertoğlu, Mithat, "Son Osmanlı Padişahı VI. Mehmet Vahideddin”, Hayat Tarih Mecmuası, Y1l:11, Cilt: 2, Sayı: 7(1 Temmuz 1975), s. 61-69.

Ünal, Tahsin, İstanbul'un İşgali 16 Mart 1920, Türk Kültürii, Yıl: IX, Sayı:101, (Mart 1971), Ankara 1971, s. 457-480. 
11 NISAN 1920(1336) TARIHHLİ TAKVIMM-İ VEKÂYI'DE KUVA-YI MILLIYE ALEYHINDE YAYINLANAN KARARLAR

\section{EKLER}

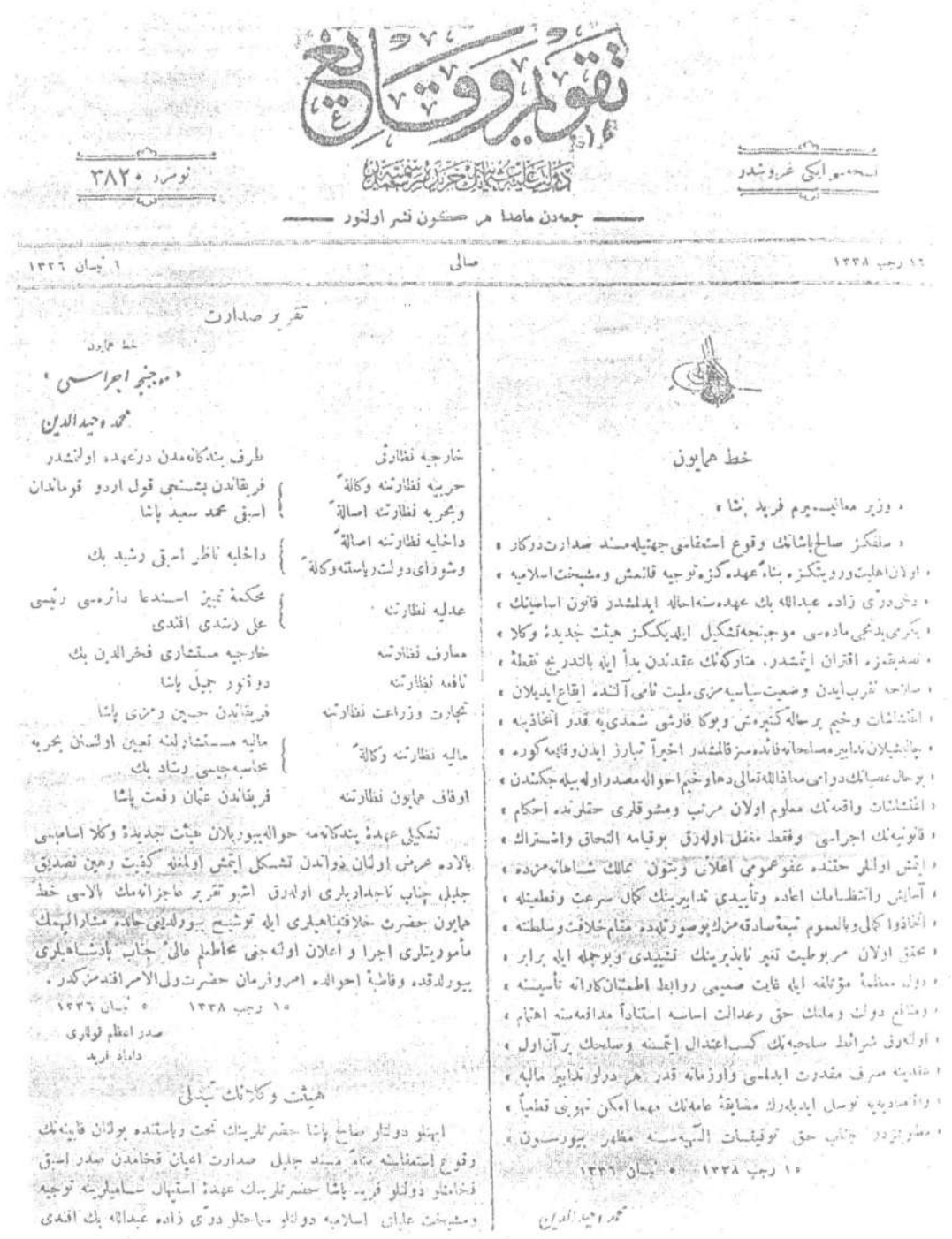

EK 1: Damad Ferid Paşanın Sadarete Getirilmesi İle İlgili Padişah Mehmet Vahdeddin'in Hatt-1 Hümâyûnu. Takvim-i Vekâyi, 11 Nisan 1336 (1920), Nr: 3824. 


\section{TUĞRA}

\section{HATT-I HÜMÂYÛN}

\section{Vezîr-i meâlî-semirim Ferid Paşa;}

Selefiniz Salih Paşa'nın vukû-u istifası cihetiyle mesned-i sadâret, derkâr olan ehliyet ve rüyetinize binaen uhdenize tevcih kılınmış ve meşihat-1 islâmiye dahi Dürrîzâde Abdullah Bey uhdesine ihale edilmişdir. Kanun-1 esâsînin yirmi yedinci maddesi mucibince teşkîl eylediğiniz heyêt-i cedîde-i vükelâ tasdikimize iktiran etmiştir. Mütarekenin akdinden bed' ile bittedric nakta-i salâha tekarrüb eden vaziyet-i siyasiyemizi milliyet nâmı altında îka' edilen iğtişâşât, vahîm bir hale getirmiş, buna karşı şimdiye kadar ittihazına çalışılan tedâbîr-i muslihâne fâidesiz kalmıştır. Ahîren tebarüz eden vekâyie göre bu hâl-i isyanın devamı maâzallahi teâlâ daha vahîm ahvale masdar olabileceğinden iğtişâşat-1 vâkıanın malum olan mürettip ve müşevvikleri haklarında ahkâm-1 kanuniyenin icrası ve fakat muğfel olarak bu kıyama iltihak ve iştirâk etmiş olanlar hakkında aff-1 umumî ilanı ve bütün memalik-i şâhânemizde âsâyiş ve intizamın iade ve te'yidi tedâbirinin kemâl-i sür'at ve katiyyetle ittihaz ve ikmâli ve bilumum tebea-i sâdıkamızın bu sûretle de makam-1 hilâfet ve saltanata muhakkak olan merbûtiyeti tegayyür nâpezîrinin teşyîdi ve bu cümle ile beraber düvel-i muazzama-i mü'telife ile gayet samîmî revabit-1 itmi'nânkârâne te'sisine ve menafi-i devlet ve milletin hak ve adalet esasına istinâden müdafaasına ihtimam olunarak şerâit-i sulhiyenin kesb-i itidal etmesine ve sulhun bir an evvel akdine sarf-1 makderet edilmesi ve o zamana kadar her türlü tedâbîr-i maliye ve iktisadîyeye tevessül edilerek muzayaka-i âmmenin mehmâ emken tehvîni kat'iyyen matlûbumuzdur.

Cenâb-1 Hak, tevfîkat-1 ilâhiyesine mazhar buyursun .

15 Receb 338/ 5 Nisan 1336

Mehmed Vahîdüddin

EK 1/A: Padişah Mehmed Vahdeddin'in Hatt-1 Hümâyûnu'nun Bu Günkü Dile Çevrilmiş Metni. 
11 NISAN 1920(1336) TARIHLİ TAKVIMM-İ VEKÂYİ'DE KUVA-YI MILLLIYE ALEYHINNDE YAYINLANAN KARARLAR

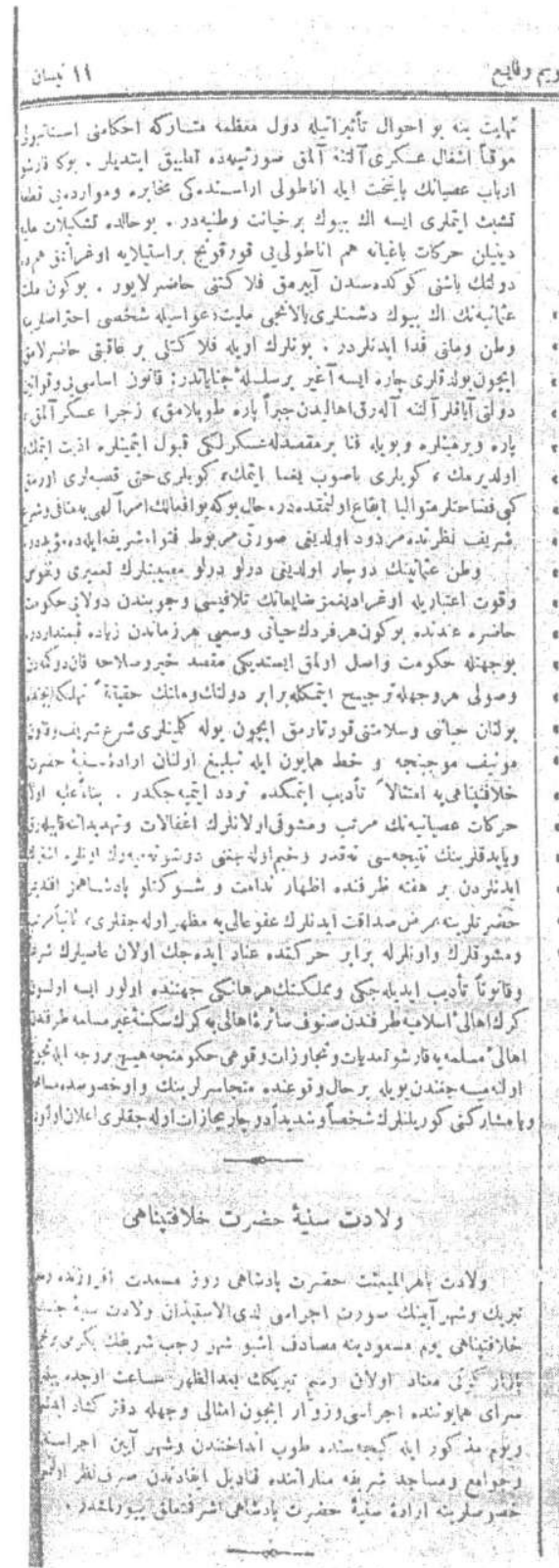

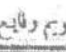

rist

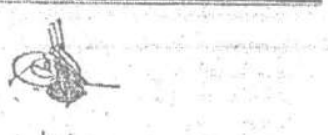

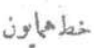

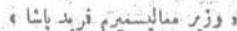

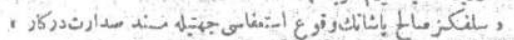

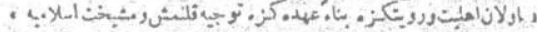

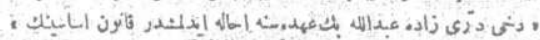

.

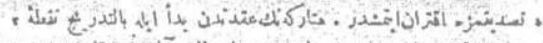

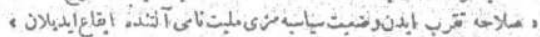

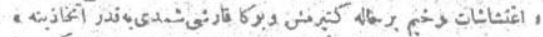

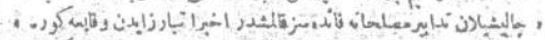

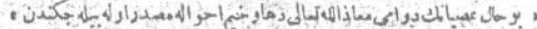

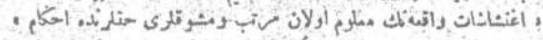

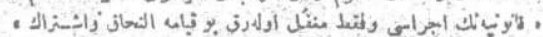

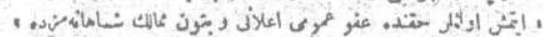

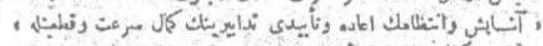

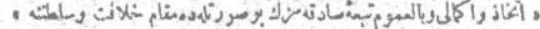

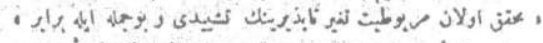

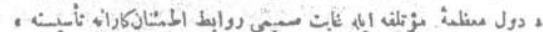

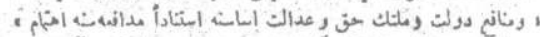

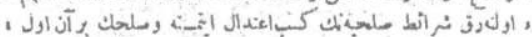

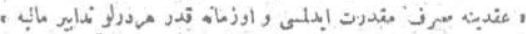

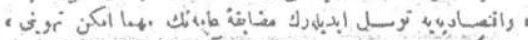

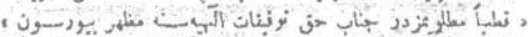
lerijle. irra

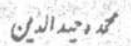

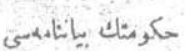

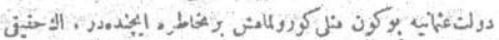

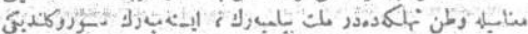

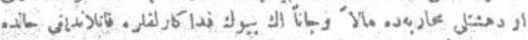

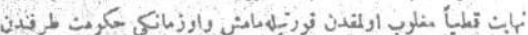

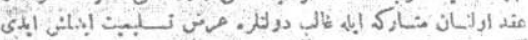

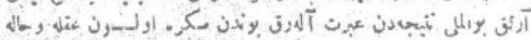

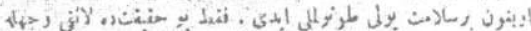

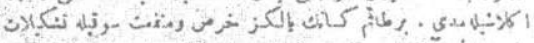

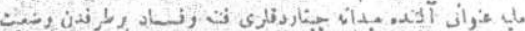

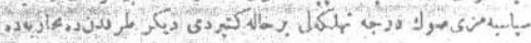

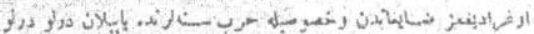

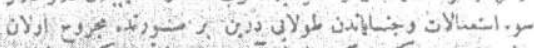

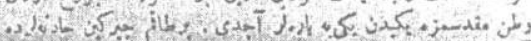

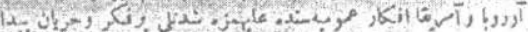

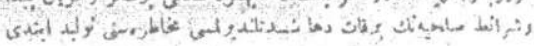

EK II: Damad Ferid Paşa Hükûmeti’nin Beyannamesi Kaynak: Takvim-i Vekâyi, 11 Nisan 1336 (1920), Nr:3824. 


\section{HÜKÛMETIN BEYANNAMESI}

Devlet-i Osmaniye bugün misli görülmemiș bir muhatara içindedir. En hakikî mânasıyla vatan tehlikededir. Millet bilmiyerek, istemiyerek sürüklendiği o dehşetli muharebede mâlen ve cânen en büyük fedakârlıklara katlandığı halde nihayet kat-iyyen mağlûb olmakdan kurtulamamıs ve o zamanki hükûmet tarafından akdolunan mütâreke ile gâlib devletlere arz-1 teslimiyet edilmiş idi. Artık bu elemli neticeden ibret alarak bundan sonra olsun, akla ve hâle uygun bir selâmet yolu tutmalı idi. Fakat bu hakîkat de, lâyıkı vechile anlaşılamadı. Birtakım kesânın yalnız hırs ve menfaat sevkıyle teşkilât-ı milliye unvanı altında meydana çıkardıkları fitne ve fesâd, bir taraftan vaziyet-i siyâsiyemizi son derece tehlikeli bir hâle getirdi. Diğer taraftan da muharebede uğradığımız zâyiatdan ve husûsiyle harp senelerinde yapılan türlü türlü sûiistimâlât ve cinâyâtdan dolayı derin bir suretde mecruh olan vatan-1 mukaddesimize yeniden yeniye yaralar açtı. Bir takım çirkin hâdiselerde, Avrupa ve Amerika efkâr-1 umûmîyesinde aleyhimize şiddetli bir fikir ve cereyan peyda ve şerâit-i sulhiyenin bir kat daha şiddetlendirilmesi muhatarasını tevlîd etti. Nihayet yine bu ahval tesiratiyle Düvel-i Muazzama mütareke ahkamını, İstanbul'u muvakkaten işgal-i askerî altına almak suretiyle de tatbik ettiler Buna karşı erbâb-1 1syânın, pâyitaht ile Anadolu arasındaki muhabere ve muvaredeyi kat'a teşebbüs etmeleri ise, en büyük hıyanet-i vataniyedir. Bu halde "teşkilât-1 milliye" denilen harekât-1 bâğıâne, hem Anadolu'yu korkunç bir istilâya uğratmak hem de devletin başını gövdesinden ayırmak felâketini hazırlıyor. Bugün millet-i Osmâniye'nin en büyük düşmanları, yalancı milliyet davasıyla şahsî ihtiraslarına vatan ve milleti fedâ edenlerdir. Bunların, öyle felâketli bir âkıbeti hazırlamak için buldukları çâre ise ağır bir silsile-i cinâyâtdır. Kanun1 esasîyi ve kavânîn-i devleti ayaklar altına alarak ahâliden cebren para toplamak, zecren asker almak, para vermiyenlere ve böyle fenâ maksatla askerliği kabul etmiyenlere eziyet etmek, öldürmek, köyleri basıp yağma etmek, köyleri hattâ kasabaları vurmak gibi fezâhatlar mütevâliyen îka olunmakdadır. Halbuki bu ef'âlin emr-i ilâhiye mûnâfî̀ ve şer'-i şerîf nazarında merdud olduğu, sûret-i merbut fetvâ-y1 şerîfe ile de müeyyeddir.

Vatan-1 Osmânînin duçar olduğu türlü türlü musîbetlerin tamiri ve nüfûs ve kuvvet itibariyle uğradığımız zâyiâtın telâfisi vücûbundan dolayı hükûmet-i hâzıra indinde bugün her ferdin hayatı ve sa'yi her zamandan ziyade kıymetdârdır. Bu cihetle hükûmet, vâsıl olmak istediği maksad-ı hayır ve salâha kan dökmeden vusûlü her cihetle tercih etmekle berâber devletin ve milletin hakîkaten tehlike içinde bulunan hayatını ve selâmetini kurtarmak için yola gelmiyenleri şer'-i şerîf ve kanun-1 münîf mucibince ve hatt-1 hümâyun ile tebliğ olunan irade-i seniyye-i hazret-i hilâfetpenâhiye imtisâlen te'dib etmekte tereddüd etmeyecektir. Binaenaleyh evvelâ, harekât-1 isyâniyenin mürettip ve müşevviki olanların iğfâlât ve tehdîdâtına kapılarak ve yaptıklarının neticesi ne kadar vahim olacağını düşünemeyerek onlara iştirâk edenlerden bir hafta zarfında izhâr-1 nedâmet ve şevketlû padişahımız efendimiz hazretlerine arz-1 sadâkat edenlerin aff-1 âlîye mazhar olacakları, saniyen, mürettib ve müşevviklerin ve onlarla beraber hareketde inad edecek olan âsilerin şer'an ve kanunen te'dib edileceği ve memleketin herhangi cihetinde olursa olsun ahâlî-i islâmiye tarafından sunüf-1 sâire-i 
ahâliye gerek sekene-i gayr-i müslime tarafından ahâlî-i müslimeye karșı taaddiyat ve tecâvüzât vukûu, hükûmetçe hiçbir vecih ile tecviz olunamıyacağından böyle bir hal vukuunda mütecâsirlerin ve o hususda müsâmaha ve müşâreketi görülenlerin şahsen ve şedîden dûçar-1 mücâzât olacakları ilân olunur.

Sadrazam Ferid"

EK II/A: Damad Ferid Paşa Hükûmeti'nin Yayınladığı Beyannamenin Bu Günkü Dile Çevrilmiş Metni. 


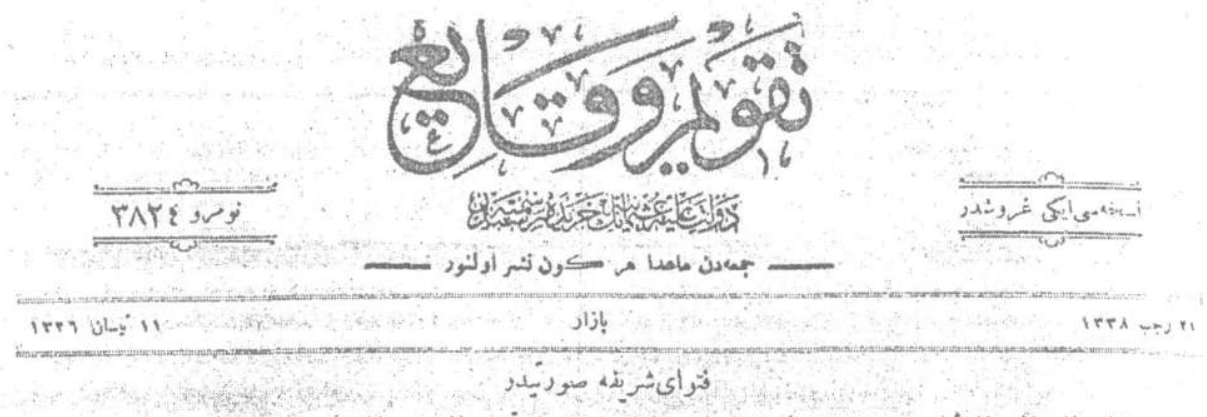

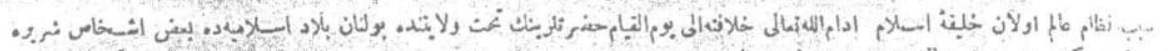

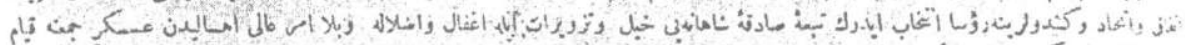

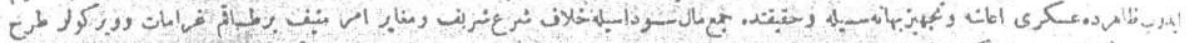

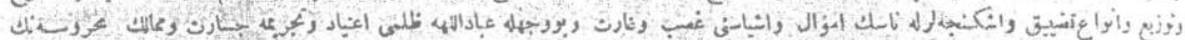

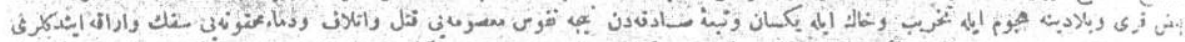

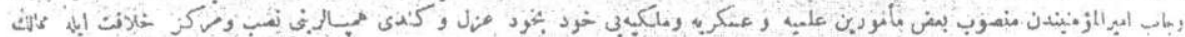

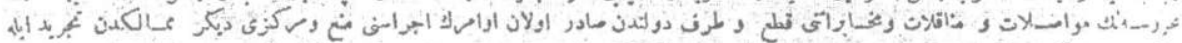

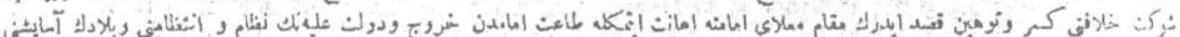

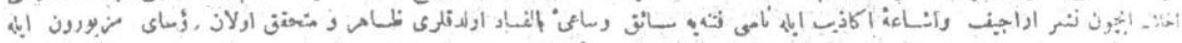

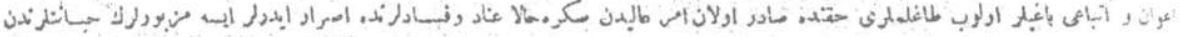

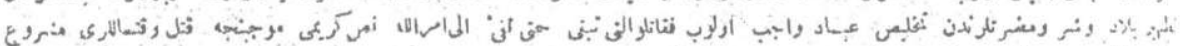

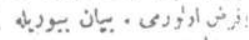
(ب)

S

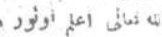

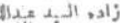

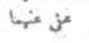

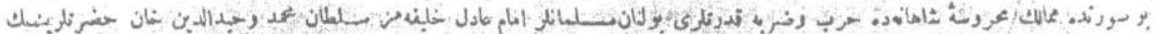

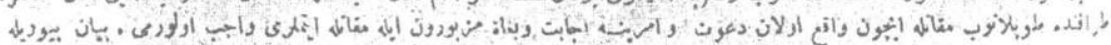

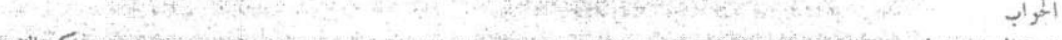

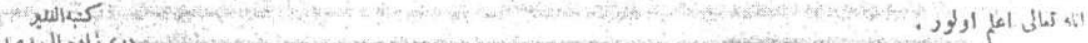
(s)

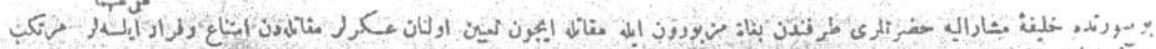

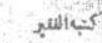

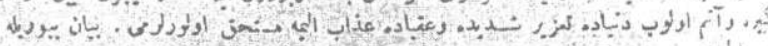

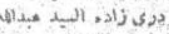
$1 \cdot \mathrm{r}^{\circ}$ .

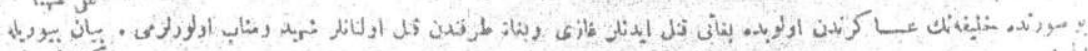
(1)

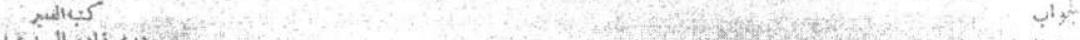

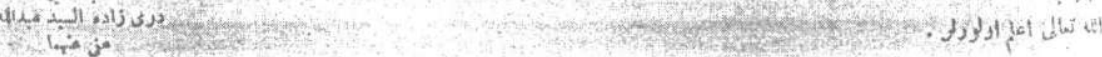

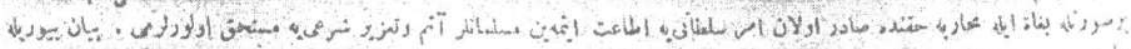
Nisitis

بأt

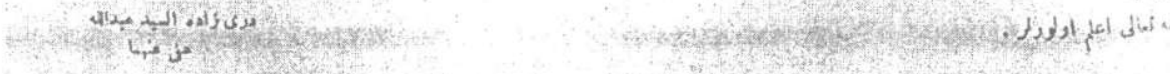

EK III: Şeyhülislâm Dürrîzâde Abdullah Efendi'nin Çıkardığı Fetva-yı Şerîfe Kaynak:Takvim-i Vekâyi, 11 Nisan 1336(1920), Nr:3824. 


\section{FETVÂ-YI ŞERIFE SÛRETIDIR}

"Sebeb-i nizâm-1 âlem olan Halife-i İslâm-edâma'llâhü teâlâ hilâfetehu ilâ yevmi'l-kıyâm- hazretlerinin taht-1 velâyetinde bulunan bilâd-1 İslâmiyede bâzı eşhâs-1 şerîre ittifak ve ittihat ve kendûlerine rüesâ intihab ederek tebea-i sâdıka-i şâhâneyi hıyel ve tezvîrât ile iğfal ve idlâle ve bilâemr-i âlî ahaliden asker cem'ine kıyam idüb zâhirde askeri iaşe ve techiz bahanesiyle ve hakikatte cem'-i mal sevdâsıyla hilâf-1 şer'-i şerif ve mugâyir-i emr-i münif bir takım garâmât ve vergiler tarh ve tevzî, ve envâ-1 tazyik ve işkencelerle nâsın emvâl ve eşyasını gasb ve gâret ve bu vechile ibâdullaha zulmü itiyad ve tecrîme cesaret ve memâlik-i mahrûsenin bâzı kurâ ve bilâdına hücum ile tahrib ve hâk ile yeksân ve tebea-i sâdıkadan nice nüfuûs-1 mâsumeyi katl ve itlâf ve dimâ-i mahkûneyi sefk ve irâka etdikleri ve cânib-i emirilmü'mininden mansub bâzı me'mûrîn-i ilmiyye ve askeriyye ve mülkiyyeyi hod be-hod azl ve kendi hempâlarını nasb ve merkez-i hilâfet ile memâlik-i mahrusenin muvâsalât ve münâkalât ve muhâberatını kat' ve taraf-ı devletden sâdır olan evâmirin icrasını men ve merkezi dîger memâlikden tercîd ile şevket-i hilâfeti kesr ve tehvîn kasd ederek makam-1 muâllay-1 imâmete ihanet etmekle tâat-i imamdan hurûç ve devlet-i aliyyenin nizâm ve intizamını ve bilâdın âsâyişini ihlaâ içün neşr-i erâcîf ve işâa-i ekâzîb ile nâsı fitneye sâik ve sâi-i-bilfesâd oldukları zâhir ve mütehakkık olan rüesây-1 mezbûrûn ile ile a'van ü etbâ1 bâgîler olup dağılmaları hakkında sâdır olan emr-i âlı̂den sonra hâlâ inad ve fesadlarında ısrar ederler ise, mezburların habâsetlerinden tathir-i bilâd ve şer ve mazarratlarından tahlîs-i ibâd vâcib olup, Fekatilû elletî tebgî Hatta tefî̀'e ilâ emrillâh nass-1 kerîmi mucebince katl ve kitalleri meşrû ve farz olur mu, beyan buyurula.

El-Cevab: Allahû teâlâ a'lem olur.

Ketebehu el-fakîr

Dürrîzâde es-seyyid Abdullah afa anhümâ

Bu sûretde memâlik-i mahrûse-i şâhânede harp ve darba kudretleri bulunan Müslümanlar, İmam-1 âdil halîfemiz Sultan Mehmed Vahîdûddin Han hazretlerinin etrâfında toplanıp mukatele için vâki olan dâvet ve emrine icabet ve buğât-i mezbûrûn ile mukatele etmeleri vâcib olur mu, beyan buyurula.

El-cevab: Allahû teâlâ a'lem olur.

Ketebehu el-fakîr

Dürrîzâde es-seyyid Abdullah afa anhüimâ

Bu sûretde halîfe-i mûşarûnileyh hazretleri tarafından buğât-1 mezbûrûn ile mukatele içün tayin olunan askerler, mukateleden imtina ve firar eyleseler, mürtekib-i kebîre ve âsim olup dünyada ta'zîr-i şedide ve ukbâda azab-1 elîme müstehak olurlar mı, beyan buyurula.

El-cevab: Allahû teâlâ a'lem olur.

Ketebehu el-fakîr Dürrîzâde es-seyyid Abdullah afa anhümâ 
Bu sûretde halifenin asâkirinden olub da buğâti katl edenler gâzi ve buğât tarafından katl olunanlar şehîd ve müsâb olurlar mı, beyan buyurula.

El-cevab: Allahû teâlâ a'lem olur.

\section{Ketebehu el-fakîr}

Dürrîzâde es-seyyid Abdullah afa anhümâ

Bu sûretde buğât ile muharebe hakkında sadr olan emr-i sultânîye itaat etmeyen Müslümanlar âsim ve ta'zîr-i şer'îye müstehak olurlar mı, beyan buyurula.

El-cevab: Allahû teâlâ a'lem olur.

Ketebehu el-fakîr

Dürrîzâde es-seyyid Abdullah afa anhümâ

21 receb 1338/11 Nisan 1336

EK III/A: Şeyhülislâm Dürrîzâde Abdullah Efendi'nin Çıkardığı Fetvâ-yı Şerîfe'nin Bu Günkü Dile Çevrilmiş Metni. 
11 NISAN 1920(1336) TARİHLİ TAKVIM-İ VEKÂYİ'DE KUVA-YI MILLIYE ALEYHINDE YAYINLANAN KARARLAR

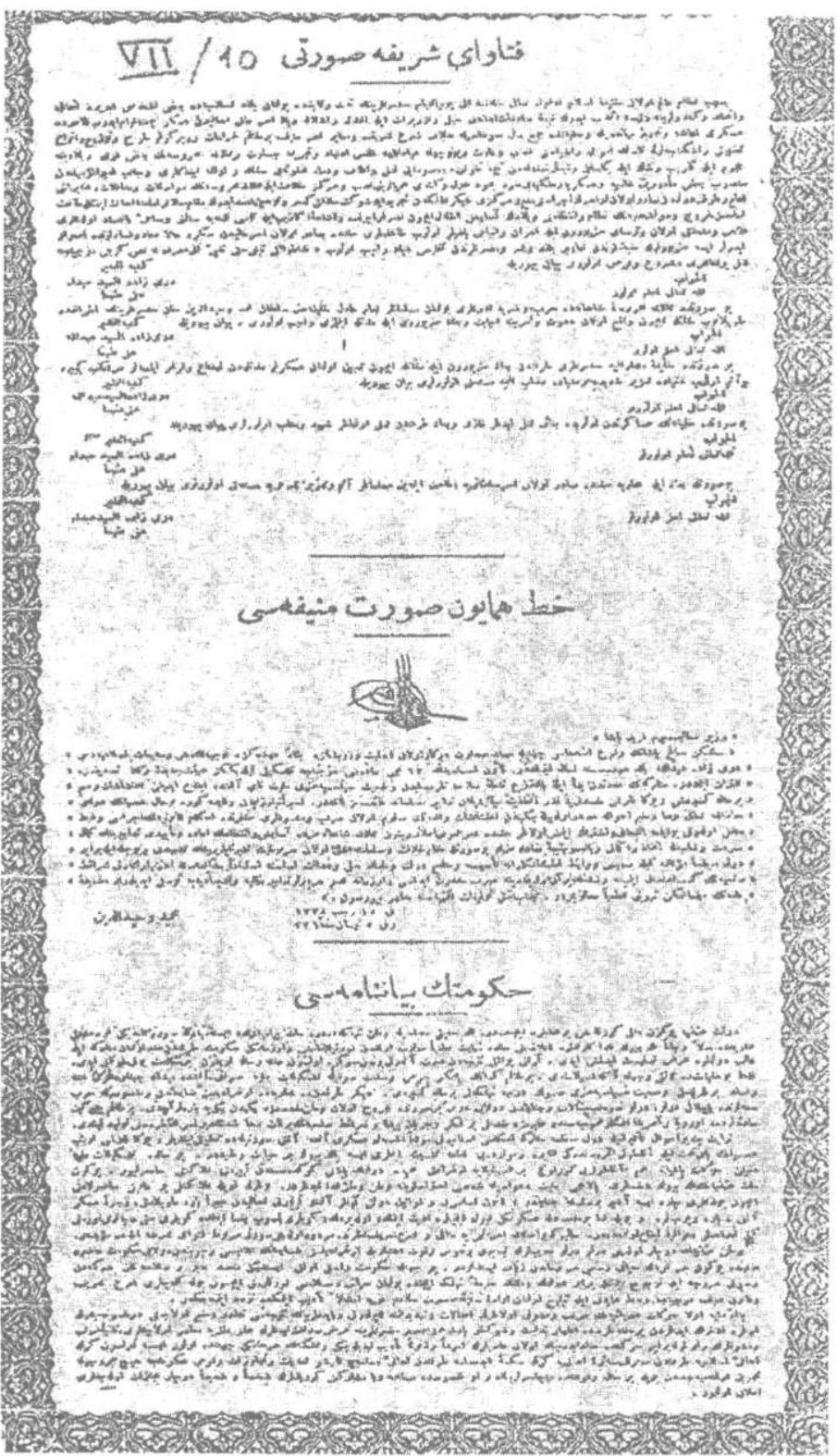

EK IV: Şeyhülislâm Dürrîzâde Abdullah Efendi'nin Fetavâ-yı Şerîfesi, Padişah Mehmed Vahdeddin'in Hatt-1 Hümâyûnu ve Damad Ferid Paşa Hükûmeti Beyannamesi'nin Aynı Sayfada Bir Araya getirilmiş Metni(İngiliz ve Yunan Uçaklarıyla Anadolu'ya Atılan Metin)Kaynak: Seçil Akgün, Murat Uluğtekin, Hilal-i Ahmer'den Kızılay'a, Ankara 2000, s. 478, EK VII/10, 


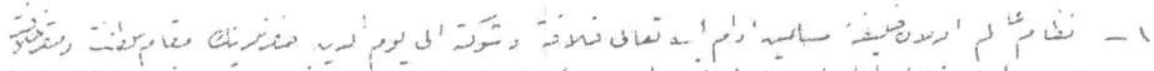

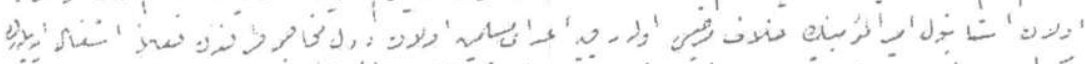

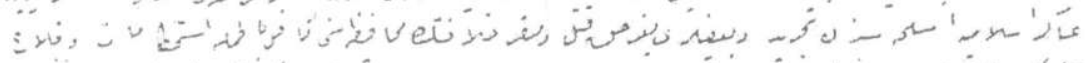
و بـ

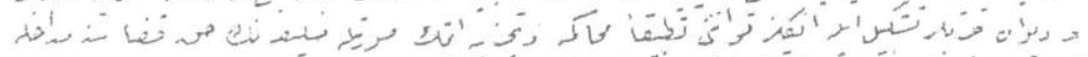

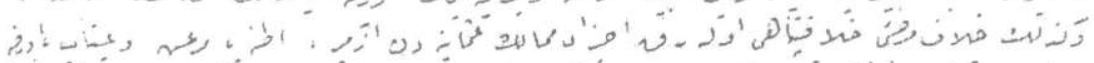

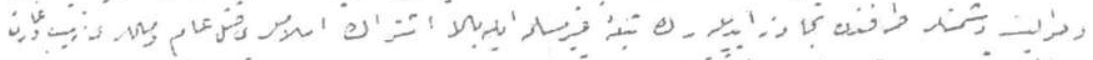

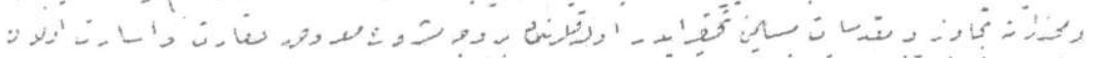

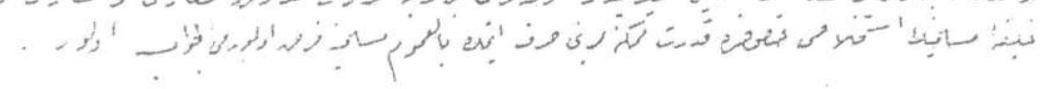

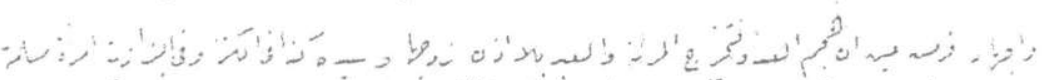

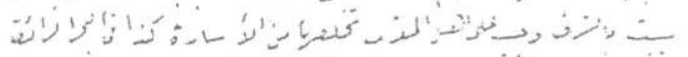

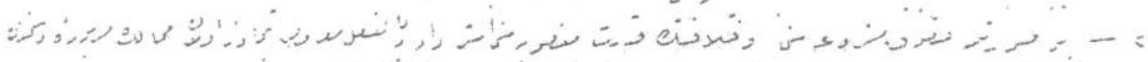

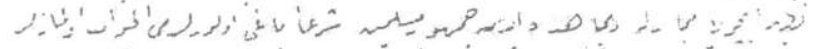

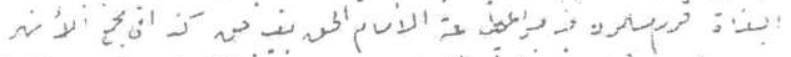

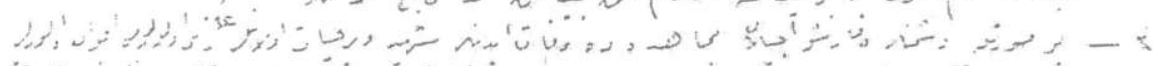
然

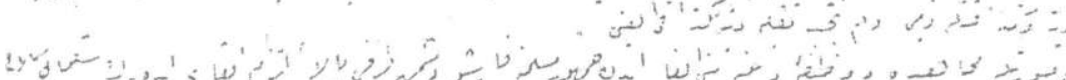

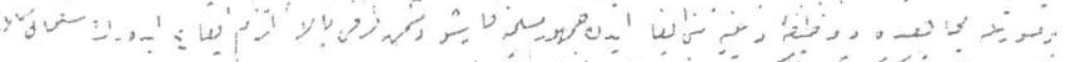

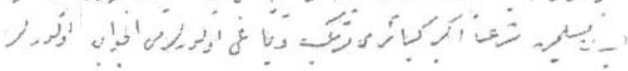

م نو ?

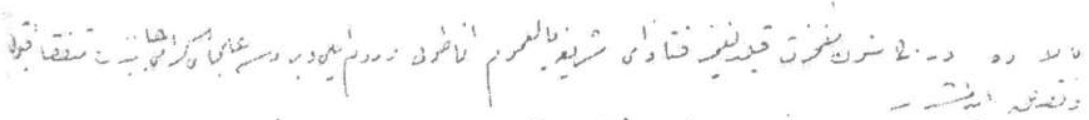

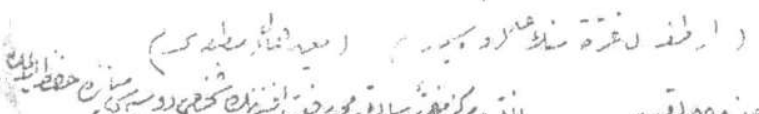

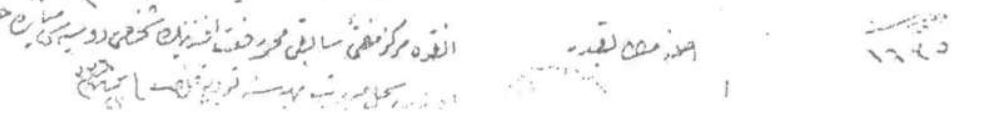

EK V: Ankara Müftüsü Mehmet Rifat Efendi'nin Başkanlığında Bir Heyet tarafından Çıkartılan Fetavâ-yı Şerîfe (Ankara Fetvâsı) Kaynak: ATASE Arşivi, Kls. 525, Ds. 8-129, F. 2. 
11 NİSAN 1920(1336) TARİHLİ TAKVIM-İ VEKÂYİ'DE KUVA-YI MILLIYE ALEYHINDE YAYINLANAN KARARLAR

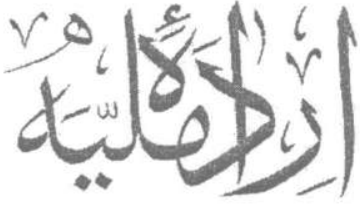

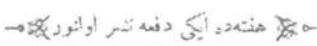

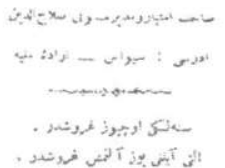

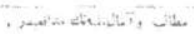

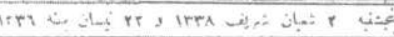

$$
\text { نتازاى ثمر نفه صصربرتلرى }
$$

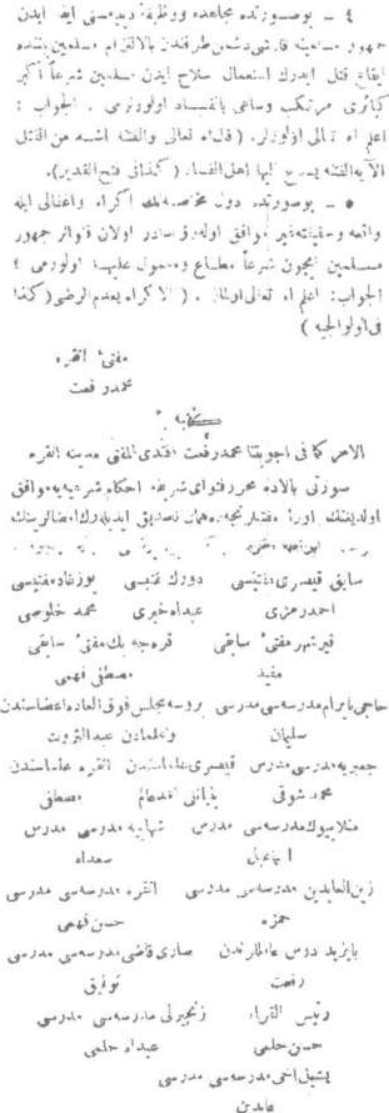

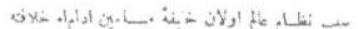

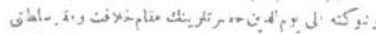

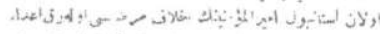

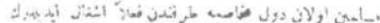

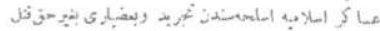

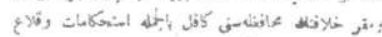

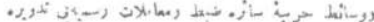

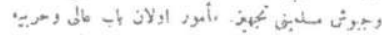

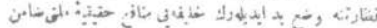

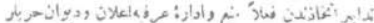

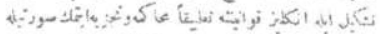

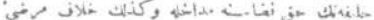

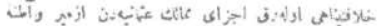

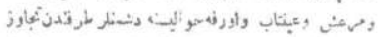

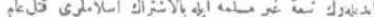

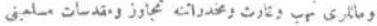

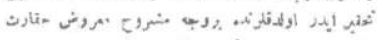

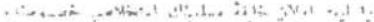

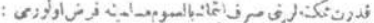

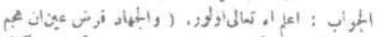

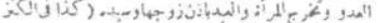

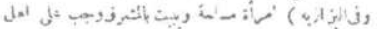

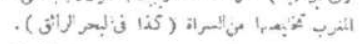

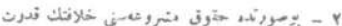

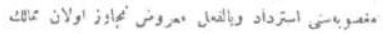

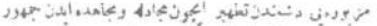

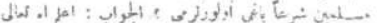

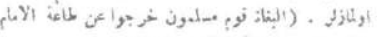

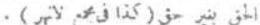

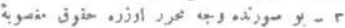

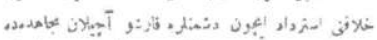

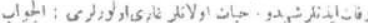
itt'

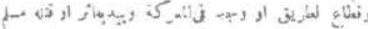

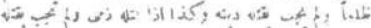
( )

EK VI: 27 Nisan 1336(1920) Tarihli İrade-i Milliye Gazetesi'nde Yayınlanan Ankara Fetvası Kaynak: İrade-i Milliye, 22 Nisan 1336 (1920), Perşembe. 
